U.S.

RELAP5 Model of the First Wall/Blanket Primary Heat Iransfer System 
This report was prepared as an account of work sponsored by an agency of the United States Government. Neither the United States Government nor any agency thereof, nor any of their employees, makes any warranty, express or implied, or assumes any legal liability or responsibility for the accuracy, completeness, or usefulness of any information, apparatus, product, or process disclosed, or represents that its use would not infringe privately owned rights. Reference herein to any specific commercial product, process, or service by trade name, trademark, manufacturer, or otherwise, does not necessarily constitute or imply its endorsement, recommendation, or favoring by the United States Government or any agency thereof. The views and opinions of authors expressed herein do not necessarily state or reflect those of the United States Government or any agency thereof. 


\title{
RELAP5 MODEL OF THE FIRST WALL/BLANKET PRIMARY HEAT TRANSFER SYSTEM
}

\author{
Emilian Popov \\ Graydon L. Yoder \\ Seokho H. Kim
}

Date Published: June 2010

\author{
Prepared by \\ OAK RIDGE NATIONAL LABORATORY \\ Oak Ridge, Tennessee 37831-6283 \\ managed by \\ UT-BATTELLE, LLC \\ for the \\ U.S. DEPARTMENT OF ENERGY \\ under contract DE-AC05-00OR22725
}





\section{RELAP5 MODEL OF THE FIRST WALL/BLANKET PRIMARY HEAT TRANSFER SYSTEM}

June 2010

Graydon L. Yoder, Jr.

Date

Group Leader, Thermal Hydraulics \& Irradiation Engineering

Jan B. Berry

Date

WBS Team Leader, U.S. ITER Cooling Water System

Brad Nelson

Chief Engineer, U.S. ITER 



\section{CONTENTS}

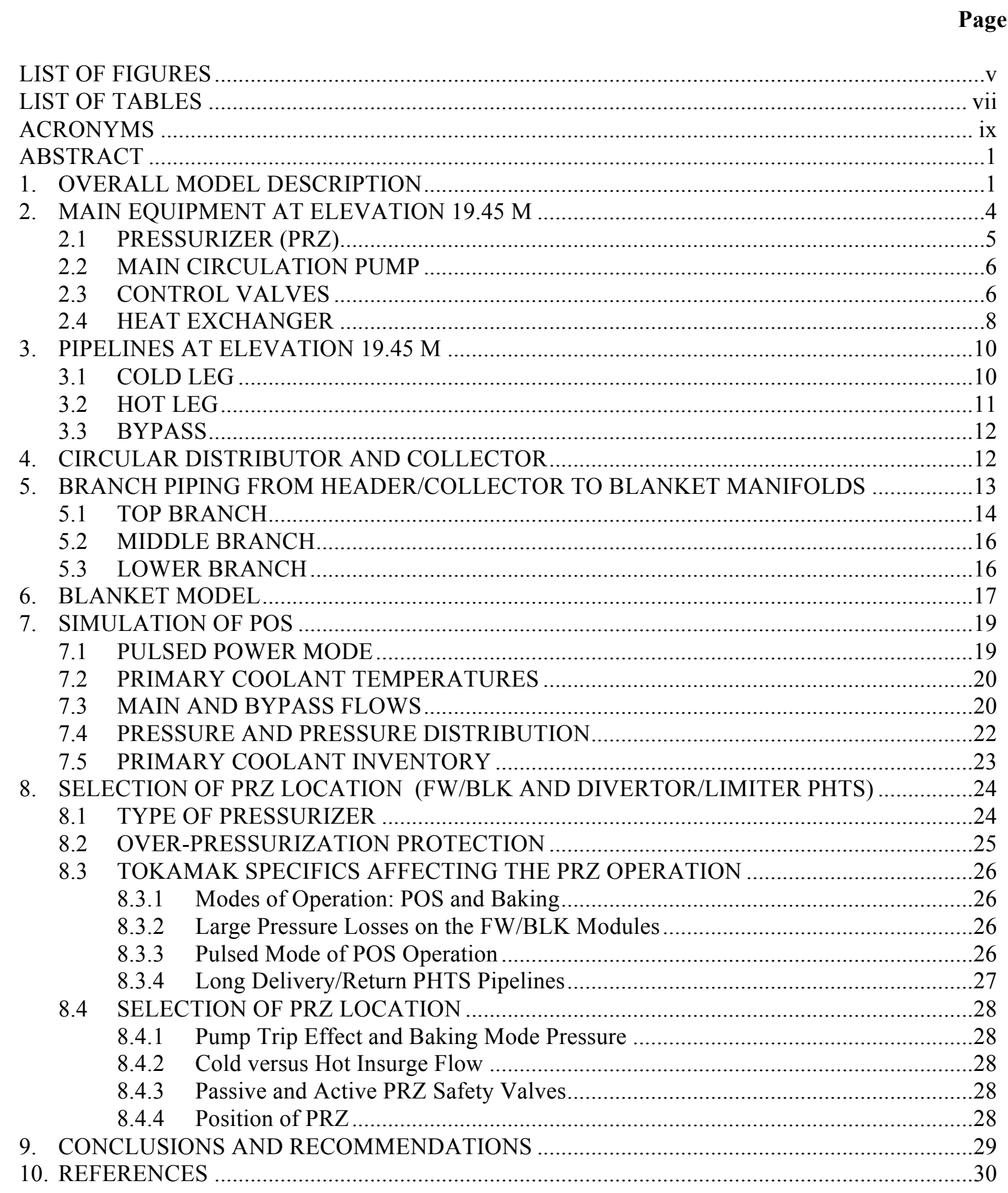





\section{LIST OF FIGURES}

Figure $\quad$ Page

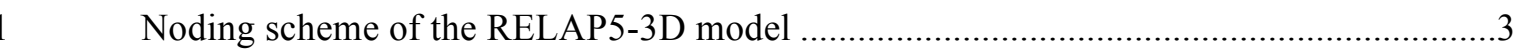

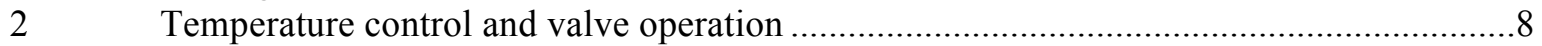

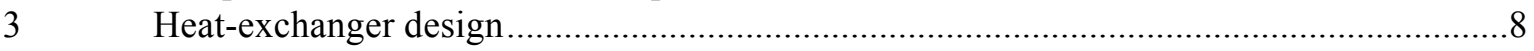

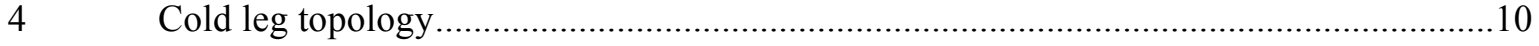

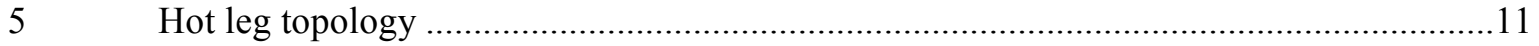

$6 \quad$ Circular distributor and collector belonging to a PHTS ................................................13

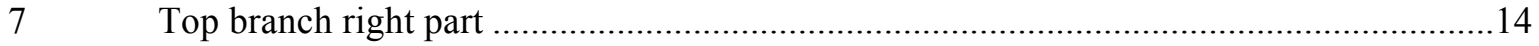

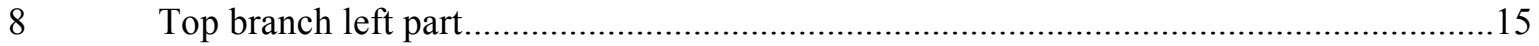

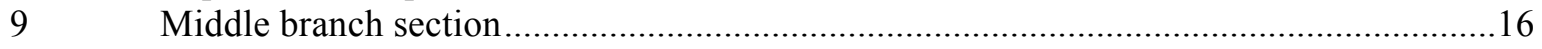

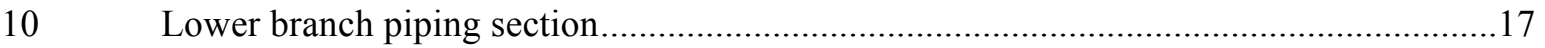

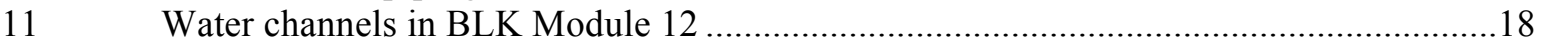

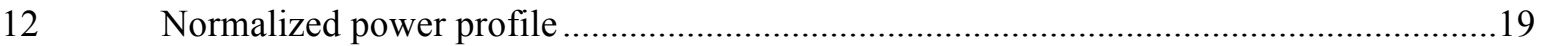

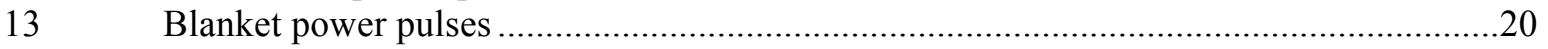

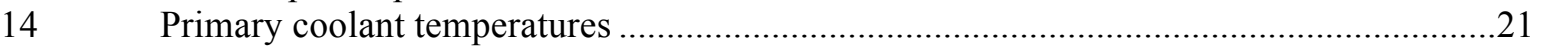

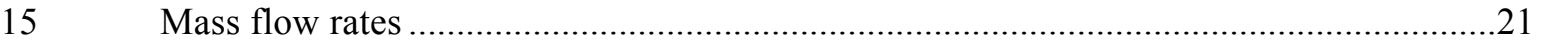

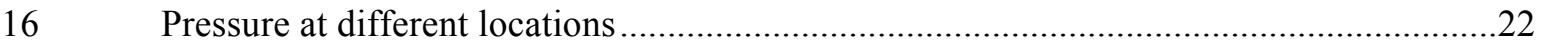

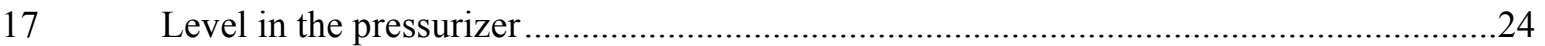

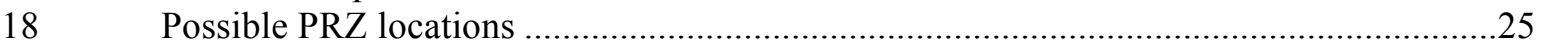

19 Normalized insurge flow and temperature at the PRZ connection ...............................27 



\section{LIST OF TABLES}

Table

Page

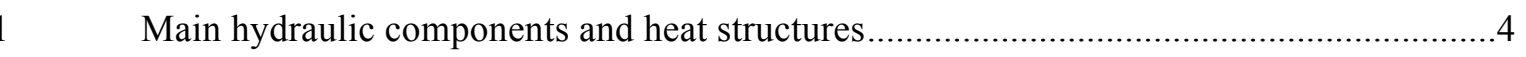

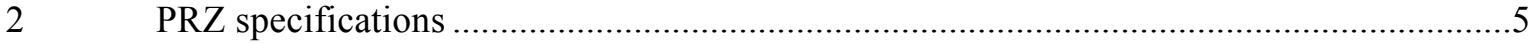

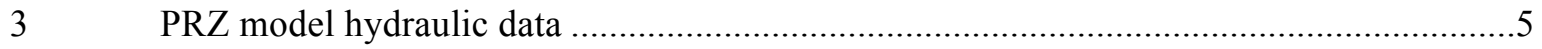

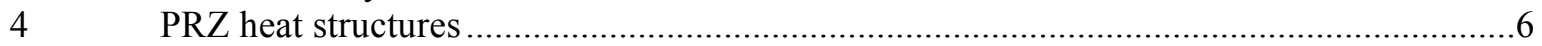

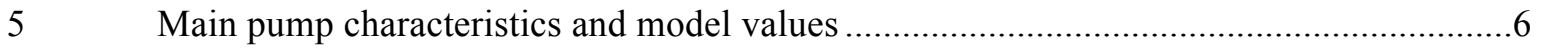

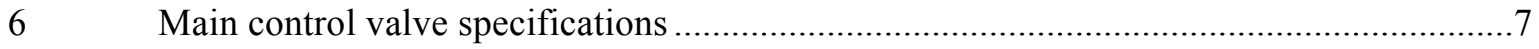

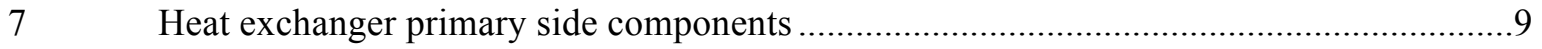

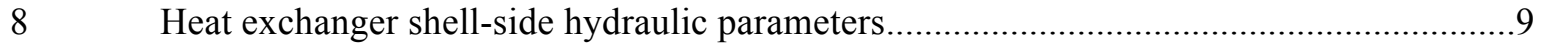

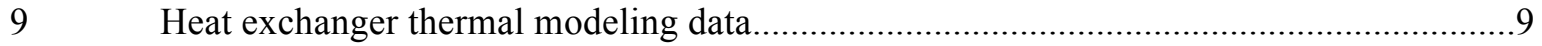

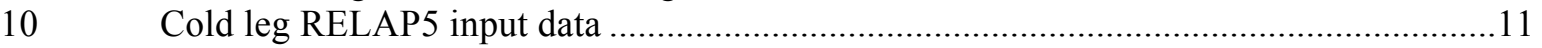

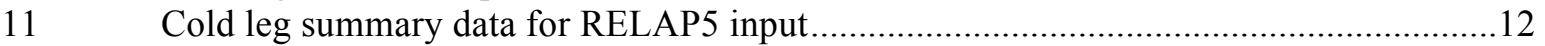

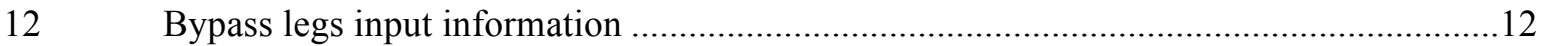

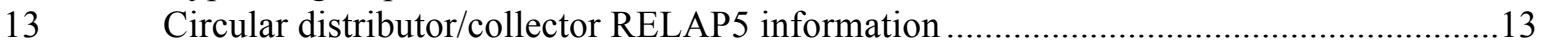

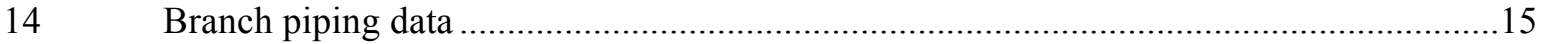





\section{ACRONYMS}

CFD

CVCS

FW/BLK

$\mathrm{HX}$

NPSH

PHTS

POS

PRZ

R5

SNAP

UCLA
Computational Fluid Dynamics

Chemical and Volume Control System

First Wall/Blanket

Heat Exchanger

Net Positive Suction Head

Primary Heat Transfer System

Plasma Operation State

Pressurizer

RELAP5

Symbolic Nuclear Analysis Package

University of California at Los Angeles 



\title{
RELAP5 MODEL OF THE FIRST WALL/BLANKET PRIMARY HEAT TRANSFER SYSTEM
}

\begin{abstract}
ITER inductive power operation is modeled and simulated using a system level computer code to evaluate the behavior of the Primary Heat Transfer System (PHTS) and predict parameter operational ranges. The control algorithm strategy and derivation are summarized in this report as well.

A major feature of ITER is pulsed operation. The plasma does not burn continuously, but the power is pulsed with large periods of zero power between pulses. This feature requires active temperature control to maintain a constant blanket inlet temperature and requires accommodation of coolant thermal expansion during the pulse.

In view of the transient nature of the power (plasma) operation state a transient system thermalhydraulics code was selected: RELAP5. The code has a well-documented history for nuclear reactor transient analyses, it has been benchmarked against numerous experiments, and a large user database of commonly accepted modeling practices exists.

The process of heat deposition and transfer in the blanket modules is multi-dimensional and cannot be accurately captured by a one-dimensional code such as RELAP5. To resolve this, a separate CFD calculation of blanket thermal power evolution was performed using the 3-D SC/Tetra thermofluid code. A 1D-3D co-simulation more realistically models $\mathrm{FW} /$ blanket internal time-dependent thermal inertia while eliminating uncertainties in the time constant assumed in a 1-D system code. Blanket water outlet temperature and heat release histories for any given ITER pulse operation scenario are calculated. These results provide the basis for developing time dependent power forcing functions which are used as input in the RELAP5 calculations.
\end{abstract}

\section{OVERALL MODEL DESCRIPTION}

The development of this model began with an ATHENA model developed by Belgatom. ${ }^{1}$ The Athena model, initially intended for draining analyses, was gradually modified during this task to perform design analyses of the Primary Heat Transfer System (PHTS) loop. After many modifications, the new model bares little resemblance to the original Belgatom model.

A large part of the Belgatom model was devoted to 2-D modeling of the first wall/blanket (FW/BLK) metal structures using a feature of the RELAP5/ATHENA code to cross connect thermal structures called an "enclosure model." That part of the Belgatom model was not used in the current model, and a totally different approach was taken toward modeling the heating in the FW/BLK. The Belgatom model reflected a design dating back to 2003 that has gone through some significant changes, including heat-exchanger design and piping sizes, which required those components to be remodeled.

The part that remained unchanged from the Belgatom model is the control system, including the control logic of valves, pressurizer heaters, and level control.

The model was built by using the Symbolic Nuclear Analysis Package (SNAP) tool ${ }^{2}$ for the RELAP5-3D code. The noding scheme is shown in Fig 1. The modeling approach is as follows.

- One single PHTS is entirely modeled. There are actually three separate first wall/blanket FW/BLK PHTSs that provide cooling to the FW/BLK components.

- The PHTS blankets themselves are modeled as a black box, a lumped single volume with a water volume that is one-third of all the FW/BLK modules. 
- Topologically, the model can be divided into the following components: PHTS equipment [pressurizer (PRZ), heat exchanger, pump, valves, etc.] located in vault 11-L4 (Ref. 3); circular distributor and collector rings; upper and lower delivery/return lines (branch lines); and the blankets. The description below will follow in the same order.

- All components that have multiple pipelines within one PHTS are lumped and modeled hydraulically together, such as the branch lines and the blankets. The weighting for each lumped component varies depending on the number of pipes in the modeled component.

- The metal structures (pipe walls) are not modeled at this time, except those belonging to the pressurizer. They may need to be added later if their thermal capacity becomes important, particularly those on the hot side where the temperature changes every power cycle.

The model consists of 40 major hydraulic and seven heat structure components; their numbers and description are summarized in Table 1.

There are also other numerous process models, control and trip variables, tables, material properties, etc., not described in this document that follow specific RELAP5 input data specifications and require knowledge of the RELAP5 code in order to be understood by reading the input deck. 


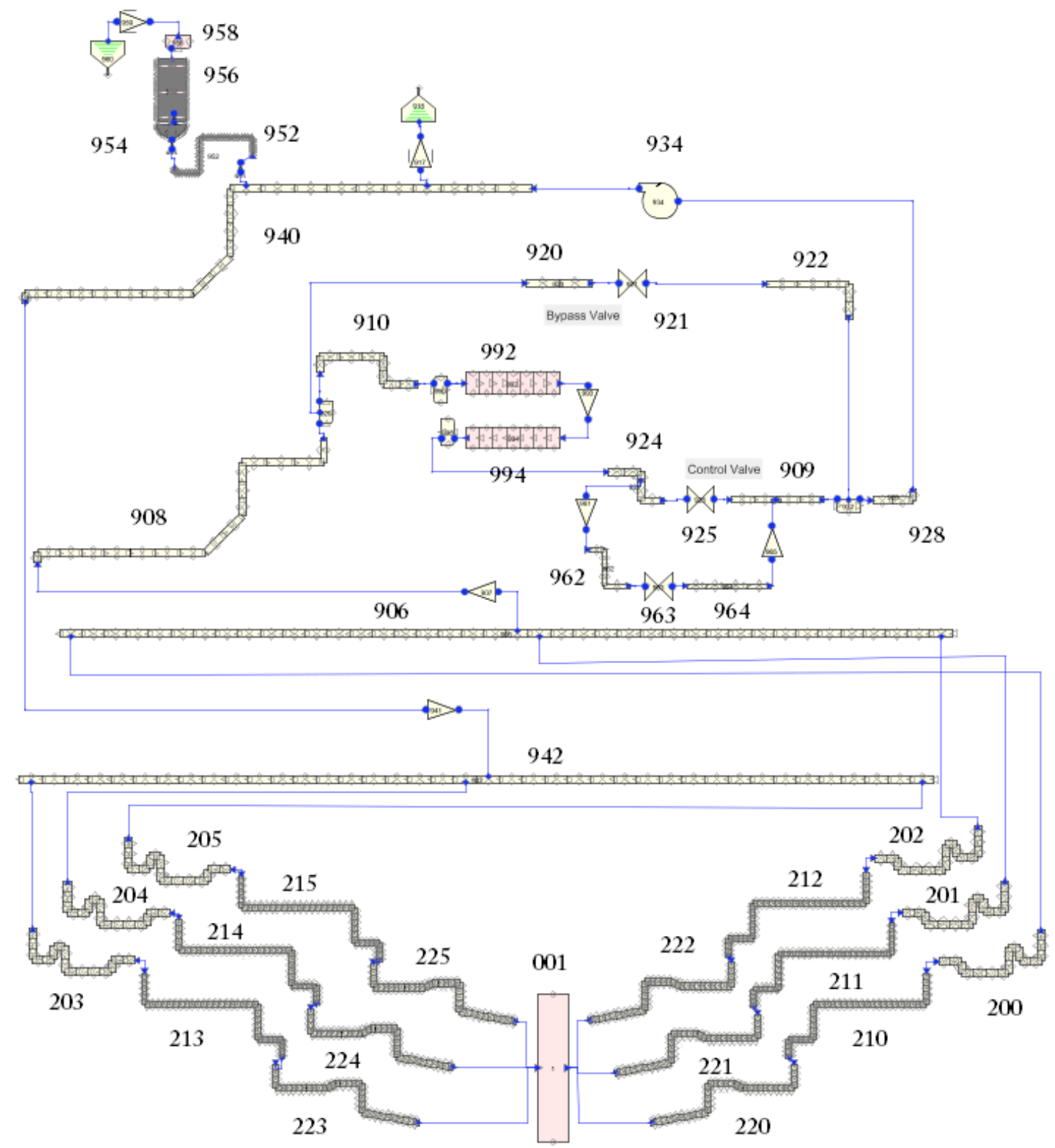

Fig. 1. Noding scheme of the RELAP5-3D model. 
Table 1. Main hydraulic components and heat structures

\begin{tabular}{|c|c|c|}
\hline No. & $\begin{array}{l}\text { RELAP5 component } \\
\text { card number }\end{array}$ & Description \\
\hline 1 & 001 & Blanket \\
\hline $2-4$ & $200-202$ & Upper return lines \\
\hline $5-7$ & $203-205$ & Upper delivery lines \\
\hline $8-11$ & $210-212$ & Middle return lines \\
\hline $12-14$ & $213-215$ & Middle delivery lines \\
\hline $15-17$ & $220-222$ & Lower return lines \\
\hline $18-20$ & $223-225$ & Lower delivery lines \\
\hline 21 & 906 & Collector \\
\hline 22 & 908 & Hot leg \\
\hline 23 & 909 & Pump leg 2 \\
\hline 24 & 910 & Heat exchanger inlet \\
\hline 25 & 920 & Bypass leg 1 \\
\hline 26 & 921 & Bypass valve \\
\hline 27 & 922 & Bypass leg 2 \\
\hline 28 & 924 & Heat exchanger outlet \\
\hline 29 & 925 & Main control valve \\
\hline 30 & 928 & Pump leg 2 \\
\hline 31 & 934 & Pump \\
\hline 32 & 940 & Cold leg \\
\hline 33 & 942 & Distributor \\
\hline 34 & 952 & Surge line \\
\hline 35 & 954 & PRZ bottom \\
\hline 36 & 956 & PRZ Vessel \\
\hline 37 & 958 & PRZ top \\
\hline 38 & 962 & Small bypass leg 1 \\
\hline 39 & 963 & Small bypass valve \\
\hline 40 & 964 & Small bypass leg 2 \\
\hline \multicolumn{3}{|c|}{ PRZ walls, heaters, and heat exchanger tube bundle } \\
\hline 1 & 9540 & PRZ bottom wall \\
\hline 2 & 9541 & Proportional heater \\
\hline 3 & 9542 & Backup heater \\
\hline 4 & 9560 & PRZ vessel wall \\
\hline 5 & 9580 & PRZ dome wall \\
\hline 6 & 9921 & HX bundle 1 \\
\hline 7 & 9941 & HX bundle 2 \\
\hline
\end{tabular}

However, some of them (power, control valves, and PRZ controls) are presented here at a high level to demonstrate the logic built into their functions.

\section{MAIN EQUIPMENT AT ELEVATION 19.45 M}

The main equipment is located at the highest point in elevation of the PHTS and consists of the PRZ, heat exchanger, pumps, control and bypass valves, low-flow pump, and the Chemical and Volume Control System (CVCS) connections. The low-flow equipment is not modeled at all, while only the letdown from the CVCS is modeled using a constant flow rate. Each particular equipment model is described below. 


\subsection{PRESSURIZER (PRZ)}

The PRZ specifications used in the modeling are taken from the design basis document ${ }^{4}$ and are given in Table 2.

Table 2. PRZ specifications

\begin{tabular}{ll}
\hline \multicolumn{1}{c}{ Item } & \multicolumn{1}{c}{ Specification } \\
\hline Type & Steam-driven \\
Total internal volume, $\mathrm{m}^{3}$ & 16.5 \\
Water volume during POS, $\mathrm{m}^{3}$ & 8.8 (nominal) \\
& 9.3 (at maximum in-surge) \\
Inside diameter, $\mathrm{m}$ & 1.9 \\
Thickness of shell, mm & 50 \\
Length of shell, $\mathrm{m}$ & 6.7 \\
Major structural material & Type $304 \mathrm{~L}$ stainless steel \\
Design pressure, $\mathrm{MPa}$ & 5.0 \\
Design temperature, ${ }^{\circ} \mathrm{C}$ & 270 \\
Approximate mass, ton & 25 \\
Heater power, $\mathrm{kW}$ & 120 (proportional) \\
& 300 (back-up) \\
Flow rate of water splay, $\mathrm{kg} / \mathrm{s}$ & 0.04 (continuous) \\
& 1.0 (maximum during pulse) \\
\hline
\end{tabular}

The PRZ is modeled by pipe components $952,954,956$, and 958 according to RELAP5 nomenclature. Their hydraulic characteristics are given in Table 3, and the line connecting the PRZ to the primary loop (surge line) is part of the model.

Table 3. PRZ model hydraulic data

\begin{tabular}{llccccc}
\hline $\begin{array}{c}\text { R5 component } \\
\text { number and } \\
\text { type }\end{array}$ & $\begin{array}{c}\text { Component } \\
\text { function }\end{array}$ & $\begin{array}{c}\text { Number } \\
\text { of cells }\end{array}$ & $\begin{array}{c}\text { Overall } \\
\text { length } \\
\text { (m) }\end{array}$ & $\begin{array}{c}\text { Volume } \\
\text { (L) }\end{array}$ & $\begin{array}{c}\text { Hydraulic } \\
\text { diameter } \\
\text { (mm) }\end{array}$ & $\begin{array}{c}\text { Total } \\
\text { pressure } \\
\text { loss } \\
\text { factors }\end{array}$ \\
\hline 952-pipe & Surge line & 39 & 10.15 & 27.7 & 59 & 1.25 \\
954 - pipe & PRZ bottom & 10 & 0.95 & 1796 & - & - \\
956 -pipe & PRZ vessel & 40 & 4.62 & 13100 & - & - \\
958 -branch & PRZ dome & 1 & 0.95 & 1796 & - & - \\
\hline
\end{tabular}

The hydraulic response of the PRZ to pressure transients is affected by the thermal inertia of the PRZ metal walls. To take that into consideration, the walls are modeled as heat-conducting structures. Their description is summarized in Table 4.

To control system pressure, heaters are installed in the PRZ. There are two heaters: a proportional and a backup heater. In terms of modeling, the heaters represent heat-generating structures and are modeled with the same RELAP5 component as the PRZ metal walls. In Table 4, the information for the PRZ heaters is given. No additional information is available in the design document ${ }^{4}$ other than that in given in Table 2 . 
Table 4. PRZ heat structures

\begin{tabular}{|c|c|c|c|c|c|c|c|}
\hline $\begin{array}{c}\text { R5 } \\
\text { component } \\
\text { number }\end{array}$ & $\begin{array}{l}\text { Component } \\
\text { function }\end{array}$ & $\begin{array}{c}\text { Left } \\
\text { thermal } \\
\text { condition }\end{array}$ & $\begin{array}{c}\text { Right } \\
\text { thermal } \\
\text { condition }\end{array}$ & $\begin{array}{l}\text { Overall } \\
\text { length } \\
\text { (m) }\end{array}$ & $\begin{array}{c}\text { Area } \\
\left(\mathbf{m}^{2}\right)\end{array}$ & $\begin{array}{c}\text { Thickness } \\
\text { (mm) }\end{array}$ & Material \\
\hline 9540 & PRZ bottom & Pipe-954 & $90 \mathrm{~W} / \mathrm{m}^{2}$ & Sphere & 2.00 & 30 & SS 316 \\
\hline 9560 & PRZ vessel & Pipe-956 & $90 \mathrm{~W} / \mathrm{m}^{2}$ & 4.58 & 30.0 & 51 & SS 316 \\
\hline 9580 & PRZ dome & Branch-958 & $90 \mathrm{~W} / \mathrm{m}^{2}$ & Sphere & 2.00 & 30 & SS 316 \\
\hline \multicolumn{8}{|c|}{ Modeling information for PRZ heaters } \\
\hline $9541-60 \mathrm{~kW}$ & $\begin{array}{l}\text { Proportional } \\
\text { heater }\end{array}$ & - & Pipe-954 & 0.95 & 0.5 & 11 & $\mathrm{Ni}-\mathrm{Cr}$ \\
\hline $9542-300 \mathrm{~kW}$ & $\begin{array}{r}\text { Backup } \\
\text { heater }\end{array}$ & - & Pipe-954 & 0.95 & 25.1 & 11 & $\mathrm{Ni}-\mathrm{Cr}$ \\
\hline
\end{tabular}

\subsection{MAIN CIRCULATION PUMP}

No specific pump has been selected at this time, and the actual pump head and torque curves are not known. For this reason, the pump characteristics of a Westinghouse pump built in RELAP5 were used. The pump-operation-rated parameters are taken from the design basis document ${ }^{4}$ and together with the RELAP5 model values are summarized in Table 5.

Table 5. Main pump characteristics and model values

\begin{tabular}{|c|c|c|c|}
\hline Parameter type & Design values & $\begin{array}{c}\text { Parameters in the } \\
\text { model }\end{array}$ & $\begin{array}{l}\text { R5 model values } \\
\text { (component 934) }\end{array}$ \\
\hline Maximum flow rate & $71 \mathrm{~m}^{3} / \mathrm{min}$ & Rated flow rate & $1.179 \mathrm{~m}^{3} / \mathrm{s}$ \\
\hline Maximum water head & $215 \mathrm{~m}$ & Rated water head & $182.2 \mathrm{~m}$ \\
\hline Shaft power & $3660 \mathrm{~kW}$ & Rated torque & 19015 N-m \\
\hline Revolution speed & $1450 \mathrm{rpm}$ & Revolution speed & $151.8 \mathrm{rad} / \mathrm{s}$ \\
\hline Required NPSH & $22 \mathrm{~m}$ & - & - \\
\hline Available NPSH & $113 \mathrm{~m}$ & - & - \\
\hline Major structural material & SS 304L & - & - \\
\hline Design pressure & $5.0 \mathrm{MPa}$ & Moment of inertia & $420 \mathrm{~kg}-\mathrm{m}^{2}$ \\
\hline Design temperature & $270^{\circ} \mathrm{C}$ & Rated density & $958 \mathrm{~kg} / \mathrm{m}^{3}$ \\
\hline Outline dimensions & $3.5 \times 6.2 \mathrm{~m}$ & Pump water volume & $100.5 \mathrm{~L}$ \\
\hline Approximate mass & 40 ton & - & - \\
\hline
\end{tabular}

\subsection{CONTROL VALVES}

The control valves regulate the temperature of coolant supplied to the blankets. The currently adopted scheme for temperature control, keeping in mind that the power pulses, is a steady cold leg temperature of $100^{\circ} \mathrm{C}$ both during the pulse and while the pulse is off (a dwell period with zero fusion power) while maintaining a constant coolant flow rate. Temperature control uses a control valve downstream of the heat exchanger in combination with a second valve installed in a line that bypasses the heat exchanger. For example, to raise temperature, additional flow is bypassed around the heat exchanger. The two valves work in opposition (when one opens, the other closes) to assure that loop flow always remains nearly constant. The control and bypass valves in Fig. 1 are the same type of 
valve. The control is applied only to the control valve, so the bypass mirrors operate opposite to the control valve; that is, when the control valve opens, the bypass closes to the same extent. The valve specifications are shown in Table 6.

Table 6. Main control valve specifications

\begin{tabular}{ll}
\hline \multicolumn{1}{c}{ Item } & \multicolumn{1}{c}{ Specification } \\
\hline Type & Cage guided \\
Valve size & ND 550 \\
Flow rate characteristic & Equal percentage \\
Range-ability & Approx. 50 \\
Rated Cv value & 3,600 \\
Flow rate during POS, $\mathrm{kg} / \mathrm{s}$ & 1.063 (HX line), 64 (bypass) \\
Operating pressure, $\mathrm{MPa}$ & 1.5 (HX line), 1.7 (bypass) \\
Operating temperature, ${ }^{\circ} \mathrm{C}$ & 96 (HX line), 148 (bypass) \\
Major structural material & Type 304L stainless steel \\
Design pressure, $\mathrm{MPa}$ & 5.0 \\
Design temperature, ${ }^{\circ} \mathrm{C}$ & 270 \\
Outline dimensions, $\mathrm{m}$ & Face to face: 1.4, total height: 3.3 \\
Approximate mass, $\mathrm{kg}$ & 2,700 \\
\hline
\end{tabular}

The VALVE component in the RELAP5 code is used to model the control and bypass valves (components 925 and 921). Since no specific valve type has been selected for the design, information is not available to program specific valve loss coefficients $\left(\mathrm{C}_{\mathrm{v}}\right)$ versus either stem position or valve area. For now, a linear function is assumed.

Besides these two valves, a small control valve is present in the model (component 963, Table 1). This is a legacy valve from the Belgatom model. It is programmed to work in very low power regimes when a temperature control might be required. In the Plasma Operation State (POS), this valve is practically open all of the time.

An important topic related to valve operation is the logic used to provide temperature control, as illustrated in Fig. 2.

Only the lower branch of the scheme is discussed - that associated with the main heat-exchanger control valve. The top branch controls the small valve in a similar manner.

From left to right in Fig. 2, the cold leg temperature reading is compared against a temperature target setpoint $\left(100^{\circ} \mathrm{C}\right)$ in a Proportional/Integral (PI) controller and an error is produced. After introducing a dead band of 5\% and scaling down the value within the range $0-1$ in component 54 , the resultant signal is compared to the valve's current position. An error signal for valve position is generated that triggers an impulse to either open or close the valve if the error is larger (positive or negative) than $1 \%$. This impulse is scaled to give a valve opening time of 27 seconds with constant rate $(0.0371 / \mathrm{s})$. It is continuously integrated, and the resultant function is the valve opening area. 


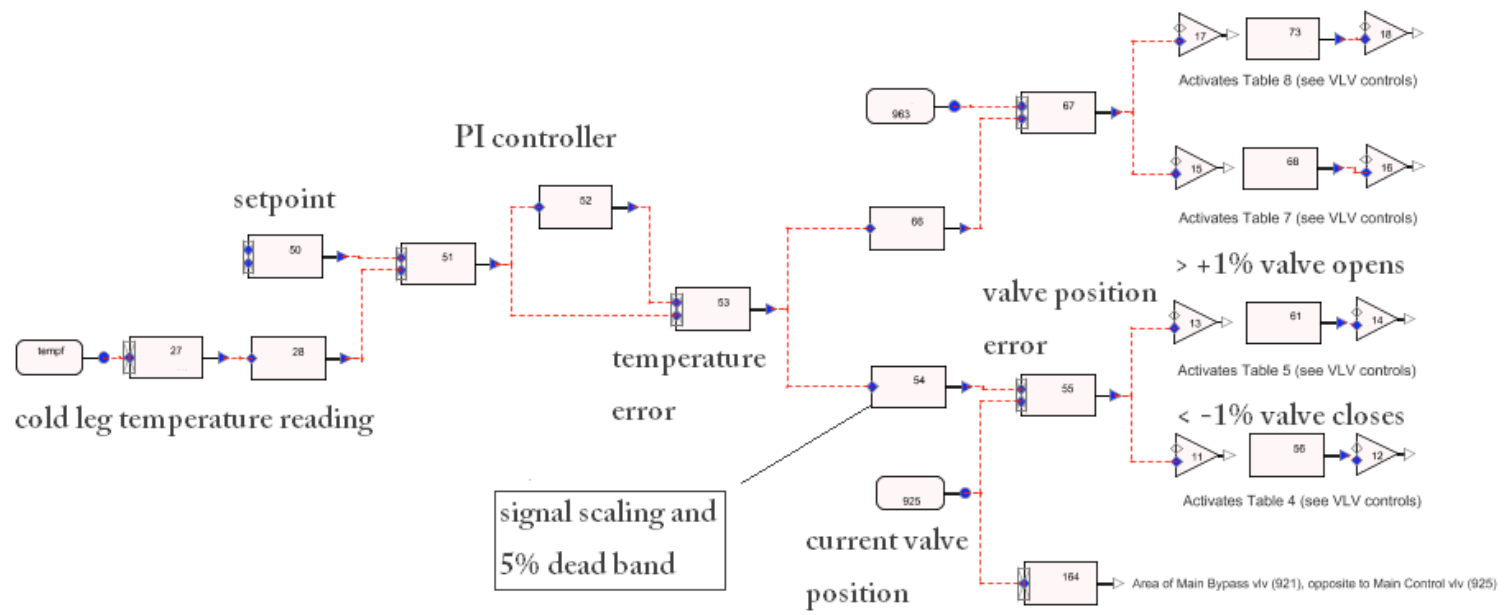

Fig. 2. Temperature control and valve operation.

\subsection{HEAT EXCHANGER}

The heat-exchanger model is based on a conceptual design performed particularly for this study. ${ }^{5}$ In this design the primary coolant flows through the tubes. A summary of the design is shown in Fig. 3.

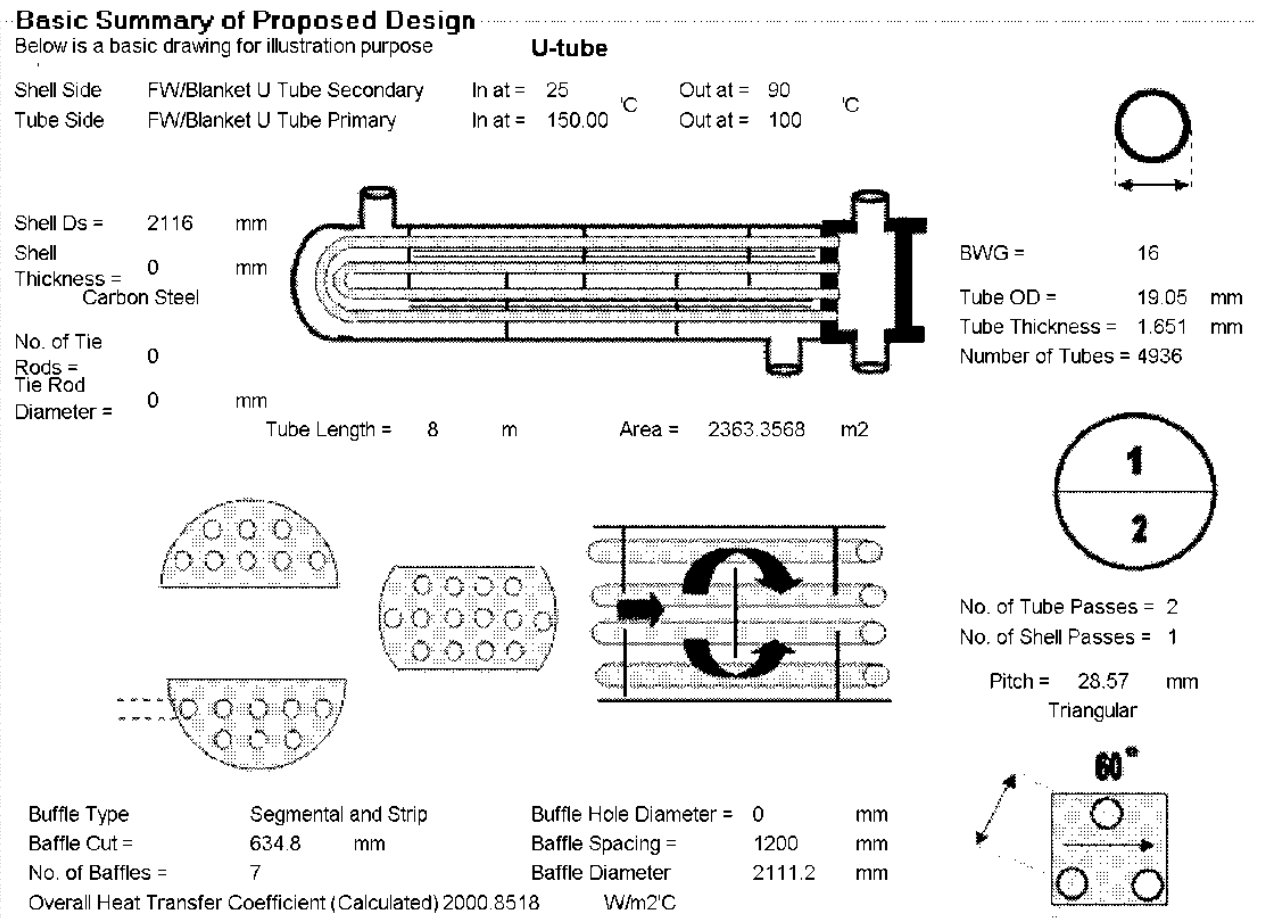

Fig. 3. Heat-exchanger design.

The heat exchanger is horizontal with a U-tube bundle and a single-flow pass on the secondary side. 
The tube bundle is modeled with four components, two of them representing the tubes and the other two the inlet/outlet chambers. The hydraulic information for those components is given in Table 7.

Table 7. Heat exchanger primary side components

\begin{tabular}{llccccc}
\hline $\begin{array}{c}\text { R5 component } \\
\text { number and } \\
\text { type }\end{array}$ & $\begin{array}{c}\text { Component } \\
\text { function }\end{array}$ & $\begin{array}{c}\text { Number } \\
\text { of cells }\end{array}$ & $\begin{array}{c}\text { Overall } \\
\text { length } \\
(\mathbf{m})\end{array}$ & $\begin{array}{c}\text { Volume } \\
\mathbf{( m}^{\mathbf{3}} \mathbf{)}\end{array}$ & $\begin{array}{c}\text { Hydraulic } \\
\text { diameter } \\
(\mathbf{m m})\end{array}$ & $\begin{array}{c}\text { Total pressure } \\
\text { loss factors }\end{array}$ \\
\hline $992(4)$ - pipe & Bundle & 8 & 8.0 & 3.84 & 15.748 & 0.05 \\
990(6)-branch & Cavities & 1 & 0.5 & 0.879 & - & 2.49 \\
\hline
\end{tabular}

The design does not include the inlet and outlet cavity sizing, and an estimate of their flow area is made based on the shell diameter $\left(2.116 \mathrm{~m}\right.$, Fig. 3), giving a value of $1.758 \mathrm{~m}^{2}$ per cavity. The length is assumed to be $0.5 \mathrm{~m}$.

The heat transfer to the secondary side is modeled as a constant boundary condition (heat-transfer coefficient), as calculated by Yoder. ${ }^{5}$ Because RELAP5 does not allow the use of a control variable for defining the sink temperature, a pipe component is used to calculate the shell-side temperature. The information for this component is summarized in Table 8 .

Table 8. Heat exchanger shell-side hydraulic parameters

\begin{tabular}{|c|c|c|c|c|c|c|}
\hline $\begin{array}{c}\text { R5 component } \\
\text { number and } \\
\text { type }\end{array}$ & $\begin{array}{l}\text { Component } \\
\text { function }\end{array}$ & $\begin{array}{c}\text { Number } \\
\text { of cells }\end{array}$ & $\begin{array}{c}\text { Volume } \\
\qquad\left(\mathbf{m}^{3}\right)\end{array}$ & $\begin{array}{l}\text { Diameter } \\
(\mathbf{m m})\end{array}$ & $\begin{array}{c}\text { Flow rate } \\
(\mathrm{kg} / \mathrm{s})\end{array}$ & $\begin{array}{c}\text { In/Out } \\
\text { temperature } \\
\left({ }^{\circ} \mathrm{C}\right) \\
\end{array}$ \\
\hline 992(4)-pipe & Shell & 8 & 16.88 & 2116 & 916 & $25 / 90$ \\
\hline
\end{tabular}

The volume of the shell side is calculated by subtracting the volume of the tube bundle from the overall shell volume. The baffles are not taken into account. The volume is as follows:

$$
\text { Vshell }=\mathrm{PI} \times(2.116)^{2} / 4.8-\mathrm{PI} \times(0.01905)^{2} / 4.8 \times 4936=16.88 \mathrm{~m}^{3} .
$$

The flow rate on the secondary side is calculated based on the total power and the temperature increase, as follows:

$$
\text { FLOW rate }=250,000 / 4.2 /(90-25)=916 \mathrm{~kg} / \mathrm{s} \text {, }
$$

where the power is taken as $250 \mathrm{MW}$ and the water-specific heat capacity is $4.2 \mathrm{~kJ} / \mathrm{kg}^{\circ}{ }^{\circ} \mathrm{C}$.

Thermally, the heat exchanger is modeled by two heat structures corresponding to the two sides of the U-tube bundle and taking into account the actual tube size. The information for the thermal modeling is given in Table 9. The data is taken from Fig. 3. In this figure the number of tubes needs to be interpreted as the number of holes in the tie plate, making the actual number of U-tubes is 2468 .

Table 9. Heat exchanger thermal modeling data

\begin{tabular}{cccccccc}
\hline $\begin{array}{c}\text { R5 } \\
\text { component } \\
\text { number }\end{array}$ & $\begin{array}{c}\text { Component } \\
\text { function }\end{array}$ & $\begin{array}{c}\text { Left } \\
\text { thermal } \\
\text { condition }\end{array}$ & $\begin{array}{c}\text { Right HTC } \\
\left(\mathbf{k W} / \mathbf{m}^{\mathbf{2}}{ }^{\circ} \mathbf{C}\right)\end{array}$ & $\begin{array}{c}\text { Overall } \\
\text { length } \\
\mathbf{( m )}\end{array}$ & $\begin{array}{c}\text { Area } \\
\left(\mathbf{m}^{\mathbf{2}}\right)\end{array}$ & $\begin{array}{c}\text { Thickness } \\
\mathbf{( m m})\end{array}$ & Material \\
\hline $9921(41)$ & U-tube & Pipe-992(4) & 4.95 & 8 & 1181.6 & 1.651 & $\mathrm{SS} 316$ \\
\hline
\end{tabular}


A fouling factor is applied on the secondary-side tubes to adjust between the clean and the real heat-transfer coefficient.

\section{PIPELINES AT ELEVATION 19.45 M}

The pipes at an elevation of $19.45 \mathrm{~m}$ are used to interconnect the main equipment located there. They can be divided in two groups based on the coolant temperature they carry: cold and hot pipes (legs).

\subsection{COLD LEG}

The cold leg is defined as a section of the piping between the main pump and the circular distribution header. A computer-aided design image of the cold leg together with the surge line to the PRZ is given in Fig. 4.

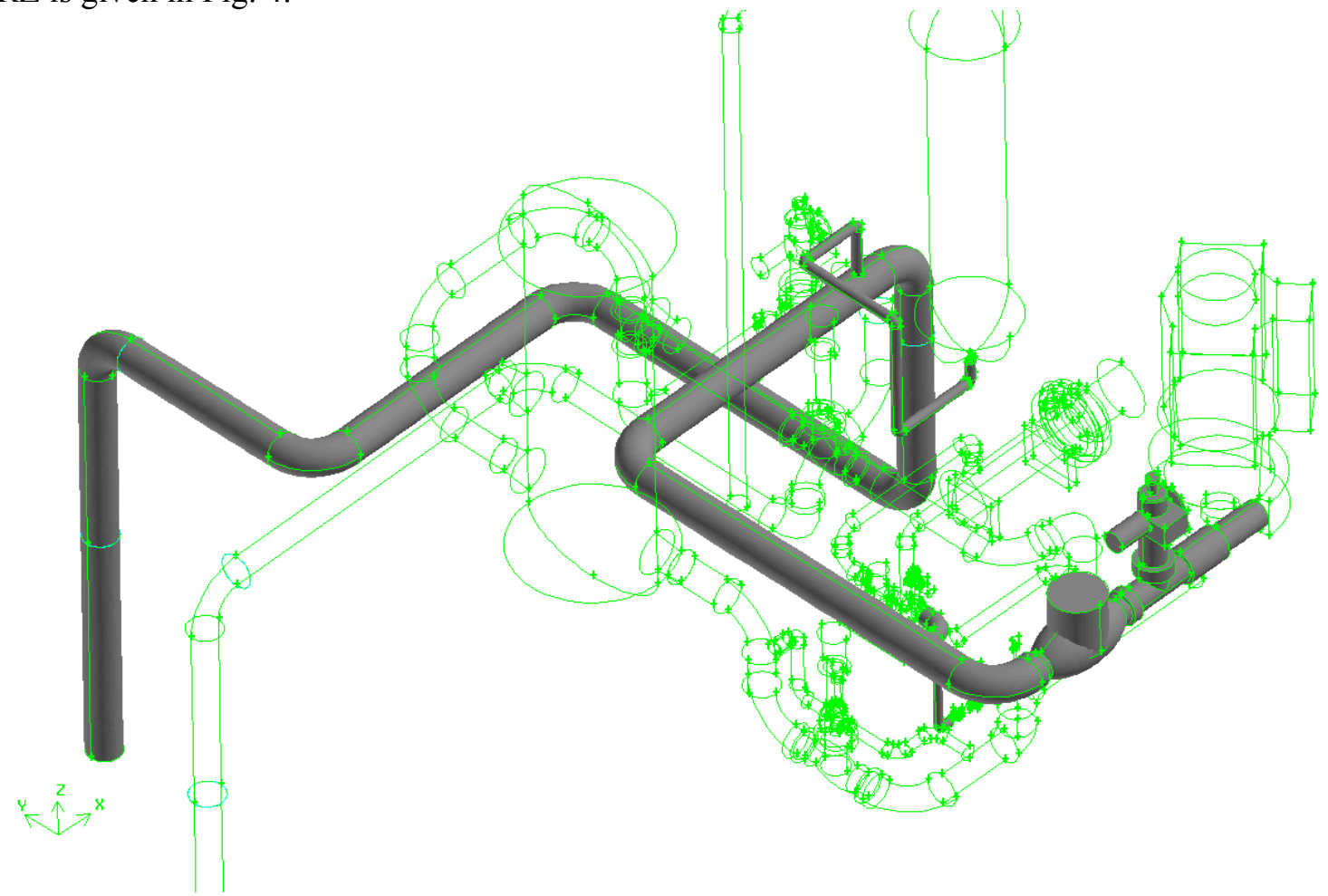

Fig. 4. Cold leg topology.

The cold leg is modeled with one single component, as summarized in Table 10. The two valves (check and isolation) shown in Fig. 4 are represented as local loss factors with values of 1.2 and 0.2, respectively. The pipe size is taken from the previously developed model for the FATHOM code. ${ }^{6}$ 
Table 10. Cold leg RELAP5 input data

\begin{tabular}{cccccccc}
\hline $\begin{array}{c}\text { R5 } \\
\text { component } \\
\text { number and } \\
\text { type }\end{array}$ & $\begin{array}{c}\text { Component } \\
\text { function }\end{array}$ & $\begin{array}{c}\text { Standard } \\
\text { size }\end{array}$ & $\begin{array}{c}\text { Number } \\
\text { of cells }\end{array}$ & $\begin{array}{c}\text { Overall } \\
\text { length } \\
\mathbf{( m )}\end{array}$ & $\begin{array}{c}\text { Volume } \\
\left.\mathbf{( m}^{\mathbf{3}}\right)\end{array}$ & $\begin{array}{c}\text { Hydraulic } \\
\text { diameter } \\
\text { (mm) }\end{array}$ & $\begin{array}{c}\text { Total } \\
\text { pressure } \\
\text { loss } \\
\text { factors }\end{array}$ \\
\hline 940 -pipe & Cold leg & - & 24 & 44.6 & 6.53 & 431.8 & 3.15 \\
\hline
\end{tabular}

\subsection{HOT LEG}

The divider between the cold and hot leg piping is the pump. The hot leg is composed of two parts: upstream and downstream of the heat exchanger (Fig. 2). The pipe size is the same as the cold leg, and an isometric view of the hot leg together with the heat-exchanger bypass is shown in Fig. 5 . Some dimensions taken from the CATIA drawings are also shown. The connection to and from the heat exchanger was modified to move the primary coolant from the shell side into the tubes.

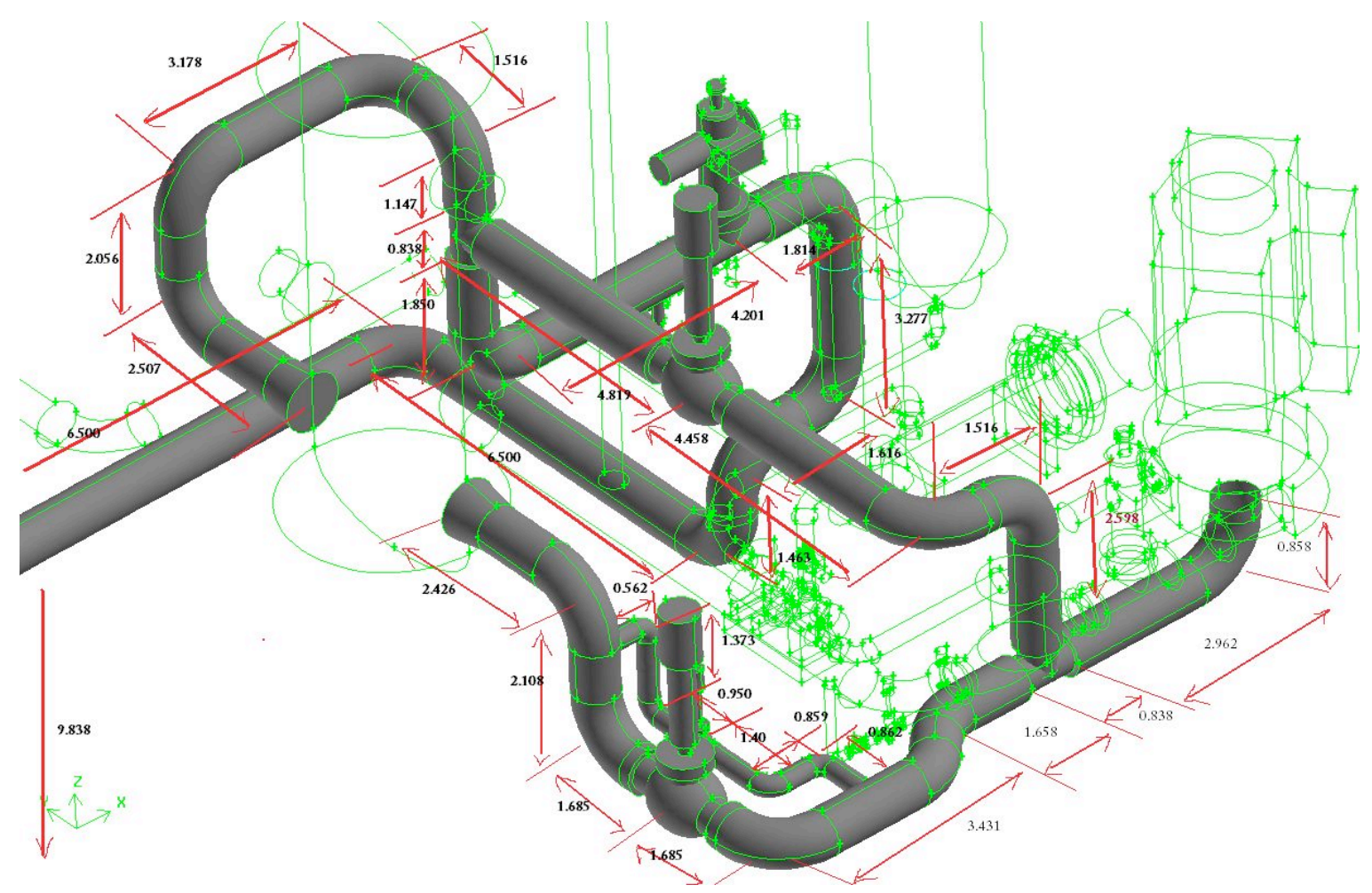

Fig. 5. Hot leg topology.

The part of the hot leg upstream of the heat exchanger is modeled with three components, while the downstream part has four and includes the main control valve. The information input into RELAP5 is given in Table 11. 
Table 11. Cold leg summary data for RELAP5 input

\begin{tabular}{|c|c|c|c|c|c|c|c|}
\hline $\begin{array}{c}R 5 \\
\text { component } \\
\text { number and } \\
\text { type }\end{array}$ & $\begin{array}{c}\text { Component } \\
\text { function }\end{array}$ & $\begin{array}{c}\text { Standard } \\
\text { size }\end{array}$ & $\begin{array}{c}\text { Number } \\
\text { of cells }\end{array}$ & $\begin{array}{c}\text { Overall } \\
\text { length } \\
\text { (m) }\end{array}$ & $\underset{\left(\mathbf{m}^{3}\right)}{\text { Volume }}$ & $\begin{array}{c}\text { Hydraulic } \\
\text { diameter } \\
(\mathrm{mm})\end{array}$ & $\begin{array}{c}\text { Total } \\
\text { pressure } \\
\text { loss } \\
\text { factors }\end{array}$ \\
\hline \multicolumn{8}{|c|}{ Upstream of heat exchanger } \\
\hline 908 -pipe & Hot leg & - & 17 & 28.9 & 4.24 & 431.8 & 1.7 \\
\hline 916-branch & To bypass & - & 1 & 0.838 & 0.123 & 431.8 & - \\
\hline 910 - pipe & HX inlet & - & 8 & 10.4 & 1.52 & 431.8 & 1.0 \\
\hline \multicolumn{8}{|c|}{ Downstream of heat exchanger } \\
\hline 924 - pipe & HX outlet & - & 5 & 6.2 & 0.91 & 431.8 & 0.5 \\
\hline 909 - pipe & Pump leg 1 & - & 4 & 6.8 & 1.0 & 431.8 & 0.5 \\
\hline 932-branch & From bypass & - & 1 & 0.838 & 0.123 & 431.8 & - \\
\hline 928 -pipe & Pump leg 2 & - & 3 & 3.8 & 0.56 & 431.8 & 0.25 \\
\hline
\end{tabular}

\subsection{BYPASS}

Two PHTS bypasses are modeled: the main heat-exchanger bypass, which contains the bypass valve, and the small bypass around the main control valve (Fig. 5). Each bypass has two legs, one upstream and one downstream of the corresponding valve. The input data for these legs are presented in Table 12.

Table 12. Bypass legs input information

\begin{tabular}{|c|c|c|c|c|c|c|c|}
\hline $\begin{array}{c}\text { R5 } \\
\text { component } \\
\text { number and } \\
\text { type }\end{array}$ & $\begin{array}{l}\text { Component } \\
\text { function }\end{array}$ & $\begin{array}{l}\text { Standard } \\
\text { size }\end{array}$ & $\begin{array}{c}\text { Number } \\
\text { of cells }\end{array}$ & $\begin{array}{l}\text { Overall } \\
\text { length } \\
\text { (m) }\end{array}$ & $\begin{array}{c}\text { Volume } \\
\left(\mathbf{m}^{3}\right)\end{array}$ & $\begin{array}{l}\text { Hydraulic } \\
\text { diameter } \\
(\mathrm{mm})\end{array}$ & $\begin{array}{c}\text { Total } \\
\text { pressure } \\
\text { loss } \\
\text { factors }\end{array}$ \\
\hline \multicolumn{8}{|c|}{ Main bypass legs } \\
\hline 920 - pipe & To valve & - & 2 & 4.8 & 0.51 & 431.8 & - \\
\hline 922 - pipe & From valve & - & 5 & 8.7 & 1.27 & 431.8 & 0.5 \\
\hline \multicolumn{8}{|c|}{ Small bypass legs } \\
\hline 962 - pipe & To valve & - & 4 & 2.9 & 0.048 & 146.3 & 0.5 \\
\hline 964 -pipe & From valve & - & 4 & 3.1 & 0.052 & 146.3 & 0.5 \\
\hline
\end{tabular}

\section{CIRCULAR DISTRIBUTOR AND COLLECTOR}

These two components serve to deliver and return the coolant to the multiple pipes that connect the circular distributor and collector to the blankets. They are shown in Fig. 6, which illustrates their position.

There are three distributor/collector pairs, one pair for each of the three PHTS loops. One pair is highlighted in Fig. 6 that belongs to one of the three loops. It is circular because it delivers coolant to three sets of blankets located 120 degrees apart from each other. The supply/return lines (branch piping) begin from these components and end at the blanket manifolds. 


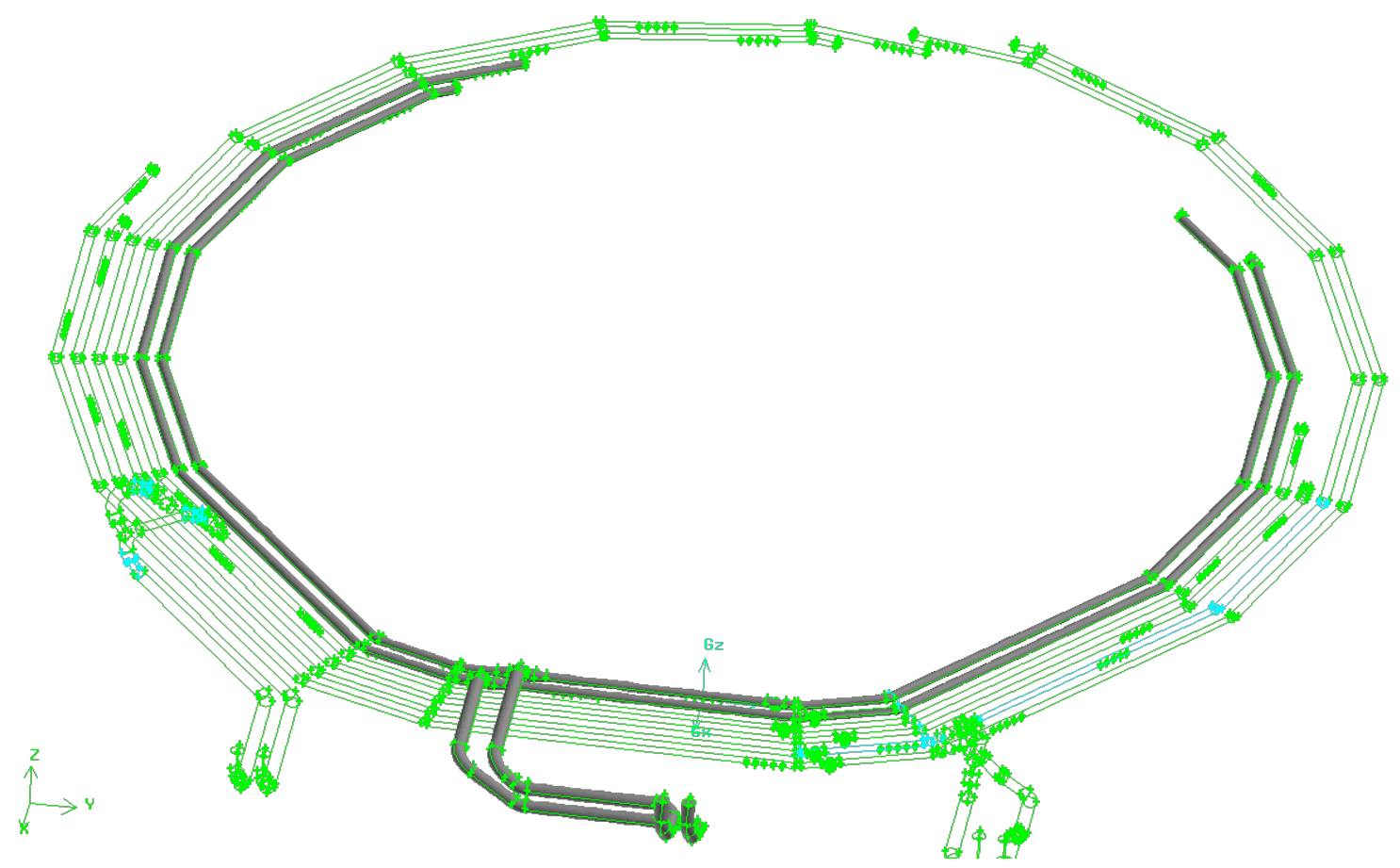

Fig. 6. Circular distributor and collector belonging to a PHTS.

The circular headers are single pipes, located lower than the PHTS, and the connection to the PHTS is in the middle, as shown in Fig. 6. They are modeled with two identical pipes. The input information is presented in Table 13.

Table 13. Circular distributor/collector RELAP5 information

\begin{tabular}{cccccccc}
\hline $\begin{array}{c}\text { R5 component } \\
\text { number and } \\
\text { type }\end{array}$ & $\begin{array}{c}\text { Component } \\
\text { function }\end{array}$ & $\begin{array}{c}\text { Standard } \\
\text { size }\end{array}$ & $\begin{array}{c}\text { Number } \\
\text { of cells }\end{array}$ & $\begin{array}{c}\text { Overall } \\
\text { length } \\
\mathbf{( m )}\end{array}$ & $\begin{array}{c}\text { Volume } \\
\left.\mathbf{( m}^{\mathbf{3}}\right)\end{array}$ & $\begin{array}{c}\text { Hydraulic } \\
\text { diameter } \\
\text { (mm) }\end{array}$ & $\begin{array}{c}\text { Total } \\
\text { pressure } \\
\text { loss } \\
\text { factors }\end{array}$ \\
\hline $942 / 906-$ pipe & $\begin{array}{c}\text { Distributor/ } \\
\text { collector }\end{array}$ & 18 "sch80 & 40 & 87.6 & 12.83 & 431.8 & - \\
\hline
\end{tabular}

\section{BRANCH PIPING FROM HEADER/COLLECTOR TO BLANKET MANIFOLDS}

The branch lines deliver and return coolant from the circular headers to the blanket. They have several pipes running in parallel, serving different sectors of the blanket. They can be further subdivided into three parts: the top, middle, and lower branches. The models of these three parts differ slightly and are described below.

Nine total branch pipes, three per loop, are each positioned 120 degrees from each other supplying the blanket manifolds. The manifolds are not a part of the branches, and they are not modeled here, primarily because the available information is incomplete. 


\subsection{TOP BRANCH}

This part begins from the circular headers down. It is distinguished from the rest of the branch piping because it is composed of four separate sections: two for each of the delivery and return lines. These two pairs have a left and a right part, which are partially illustrated in Fig. 7 and Fig. 8.

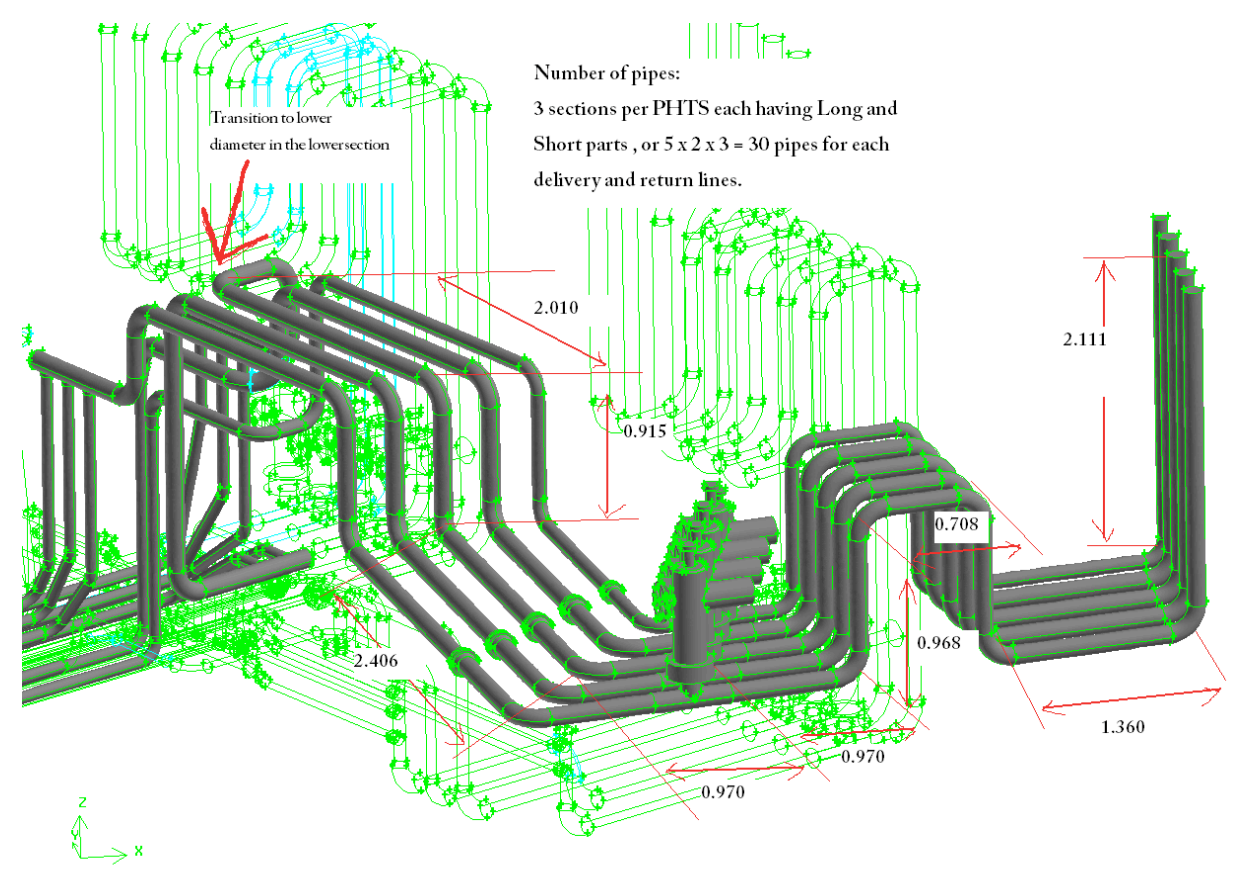

Fig. 7. Top branch right part. 


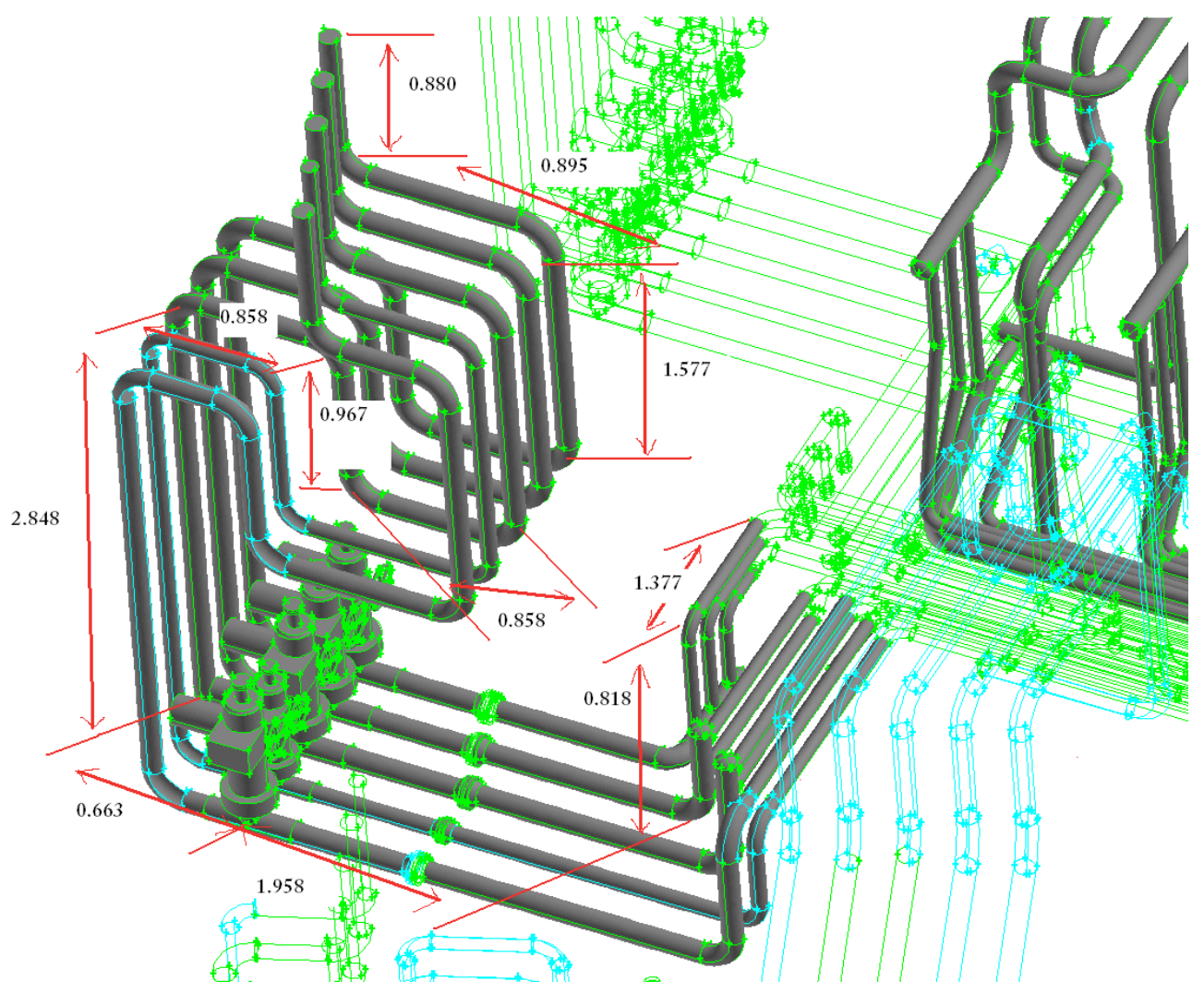

Fig. 8. Top branch left part.

For better understanding of the exact location and configuration of these lines, the design needs to be examined. Here, in the modeling of this section, some degree of approximation is used because, as seen in the figures, each line has a different length and geometric configuration. In the model, the left and the right parts of the top branches are combined together and result in an equivalent model where the numerous pipes are lumped into one. In the Fig. 1 model, the top branch part is modeled with components 200-205.

All of these components are identical, and relevant information is given in Table 14 .

Table 14. Branch piping data

\begin{tabular}{|c|c|c|c|c|c|c|c|c|}
\hline $\begin{array}{c}\text { R5 } \\
\text { component } \\
\text { number } \\
\text { and type } \\
\end{array}$ & $\begin{array}{l}\text { Component } \\
\text { function }\end{array}$ & $\begin{array}{l}\text { Standard } \\
\text { size }\end{array}$ & $\begin{array}{l}\text { Numbe } \\
\text { r of } \\
\text { cells }\end{array}$ & $\begin{array}{c}\text { Overal } \\
\text { I } \\
\text { length } \\
\text { (m) }\end{array}$ & $\begin{array}{l}\text { Volum } \\
\text { e }\left(\mathrm{m}^{3}\right)\end{array}$ & $\begin{array}{c}\text { Hydraul } \\
\text { ic } \\
\text { diameter } \\
(\mathbf{m m})\end{array}$ & $\begin{array}{c}\text { Total } \\
\text { pressure } \\
\text { loss factors }\end{array}$ & $\begin{array}{c}\text { Numbe } \\
\mathbf{r} \text { of } \\
\text { pipes }\end{array}$ \\
\hline $200-205$ & $\begin{array}{l}\text { TOP } \\
\text { branch }\end{array}$ & $6 " \operatorname{sch} 40$ & 16 & 13.66 & 2.54 & 154 & 2.45 & 10 \\
\hline $210-215$ & $\begin{array}{l}\text { MIDDLE } \\
\text { branch }\end{array}$ & $3 " \operatorname{sch} 40$ & 40 & 16.59 & 1.59 & 78 & 0.75 & 20 \\
\hline $220-225$ & $\begin{array}{l}\text { LOW } \\
\text { branch }\end{array}$ & $3 " \operatorname{sch} 40$ & 36 & 12.45 & 1.19 & 78 & 1.45 & 20 \\
\hline
\end{tabular}




\subsection{MIDDLE BRANCH}

In this section the lines split from five (top branch) to ten but are smaller in size. They all run parallel except near the vacuum vessel. Before entering the vacuum vessel, they again become four sections of five pipes each. The pipe configuration is shown in Fig. 9.

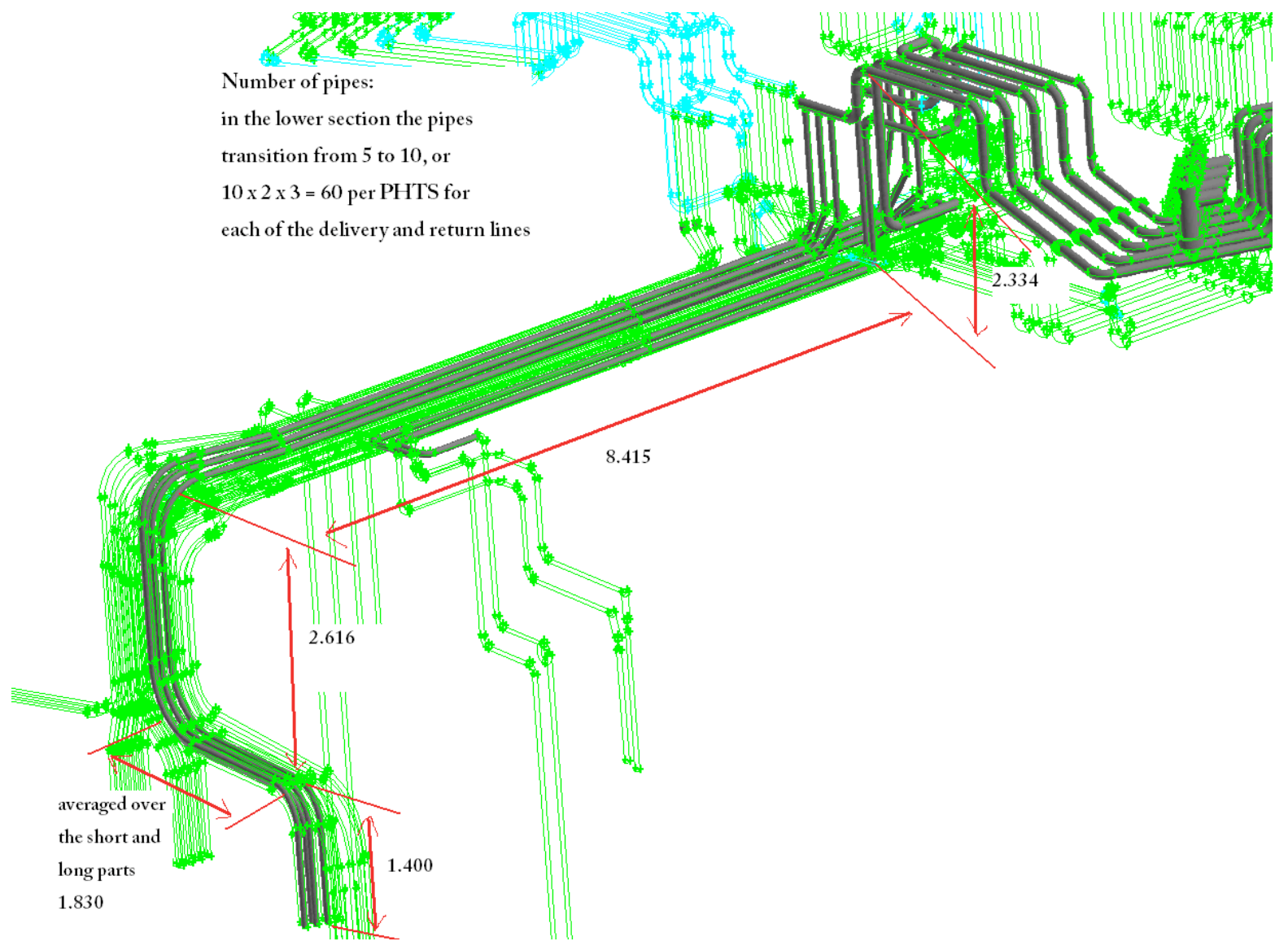

Fig. 9. Middle branch section.

The supply and the return lines run in parallel, which makes the number of pipes in the straight section equal to 40 , and are routed in a duct to facilitate leak detection. In the model, the lines are lumped in one component per set of branch pipes, the data for which are given in Table 14.

\subsection{LOWER BRANCH}

The lower branch piping is that section of the lines inside the vacuum vessel. It is a natural continuation of the middle branch, has the same number and size of pipes, and connects to the blanket manifolds. A set of lower branch piping is shown in Fig. 10, and the model data is given in Table 14.

NOTE: This section is modeled as shown; however, there is some inconsistency between this view and other design variations that are not presented here. It is possible that this section might be outdated, coming from an old design. The geometry needs to be verified as soon as the final design of the pipelines is completed. 


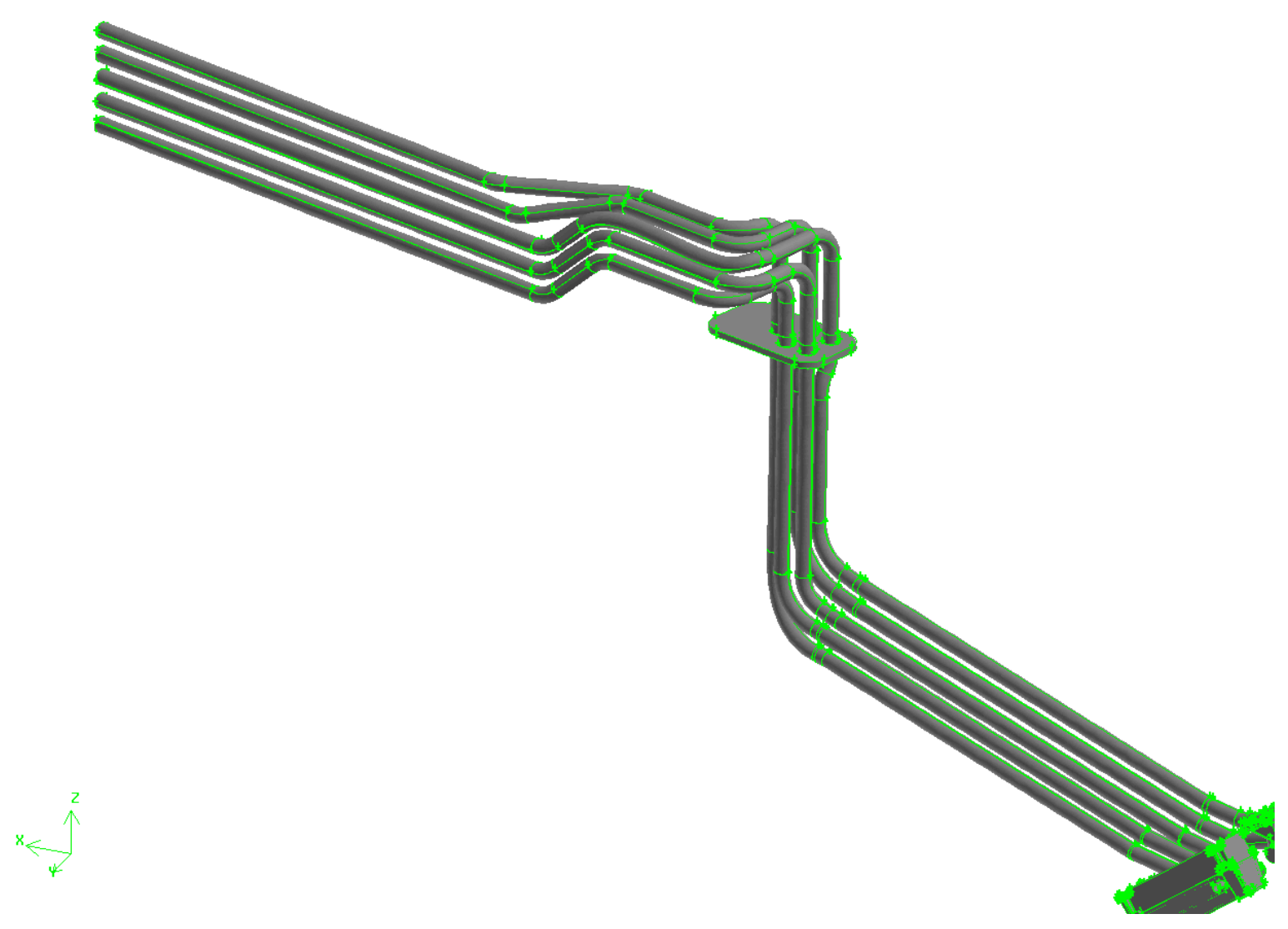

Fig. 10. Lower branch piping section.

\section{BLANKET MODEL}

The blanket is modeled as a single lumped volume and is basically treated as a black box. Such an approach was taken because the FW/BLK is a massive metal structure. It is cooled by complex coolant channels where multidimensional heat transfer is dominant. Modeling it with a onedimensional code such as RELAP5 would be very unrealistic. To illustrate that point, the water channels of BLK module 12 are shown in Fig. 11.

Positioned on the inboard and outboard of the vacuum vessel are 18 different modules. They are designed to take the heat load from the plasma (radiation) and from the direct nuclear heating (deposited heat in structures and coolant). The University of California at Los Angeles (UCLA) performs detailed Computational Fluid Dynamics (CFD) calculations based on heating rates calculated at University of Wisconsin. In the present modeling effort, results from the UCLA work are used to provide power input for the RELAP5 blanket power model.

The blanket design is under way and is not yet finalized. The current blanket power model is, therefore, not final and is subject to updates as soon as new information for the blankets becomes available. 


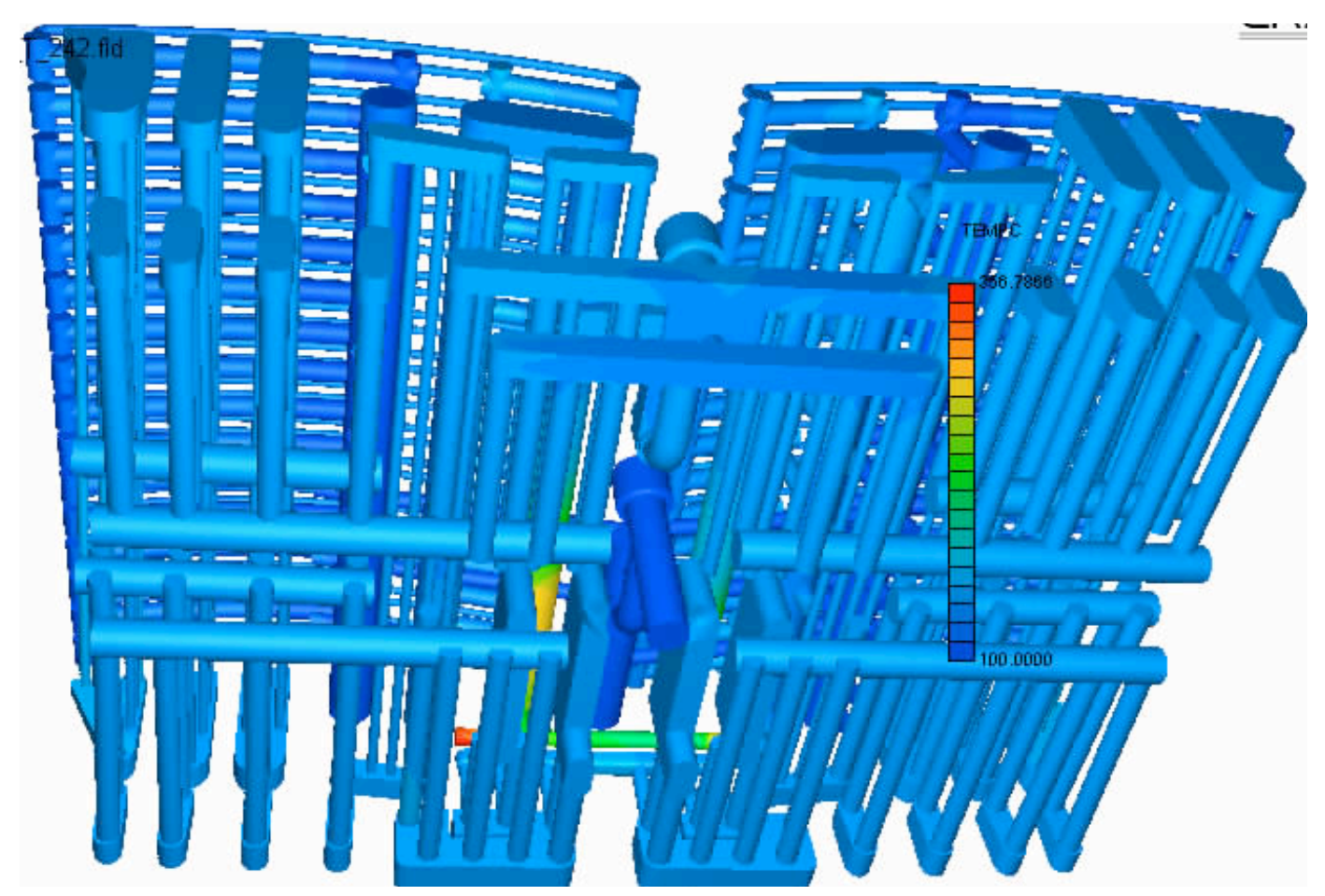

Fig. 11. Water channels in BLK Module 12.

The model relies on the following main assumptions and approximations:

1. The overall blanket volume belonging to each PHTS loop is $28 \mathrm{~m}^{3}$ (Ref. 4)

2. The directly deposited heat in the coolant is calculated by a 3D flow and heat transfer conjugate solution taking into account the heating rates in the different blanket materials. The sum of the power removed from metal structures and the directly deposited power in the coolant are used as input in the RELAP5 code.

3. Nuclear decay heat is not calculated and is not taken into account.

4. Blanket module 4 is used as a representative module for the whole blanket; for example, no other module designs are used to develop the heating profile. The result is scaled to the nominal power and is used as input for the RELAP5 code. The power profile is shown in Fig. 12 and is calculated by Ying in the 2009 CFD Analysis for BM04 Model. ${ }^{7}$

5. The module 4 calculation does not include the $\mathrm{FW}$, because it has not yet been designed. Therefore, adding the FW may change the profile.

The power profile in Fig. 12 is coded into RELAP5 so that it repeats every power cycle (1800 seconds). The power is directly deposited in the coolant (e.g., no thermal inertia of the blanket structures), causing no delay between the time the pulse starts and the heated coolant leaves the blanket. This approximation is acceptable since the residence time in the blanket is small ( $\sim 6$ seconds) compared to the rest of the circuit. 


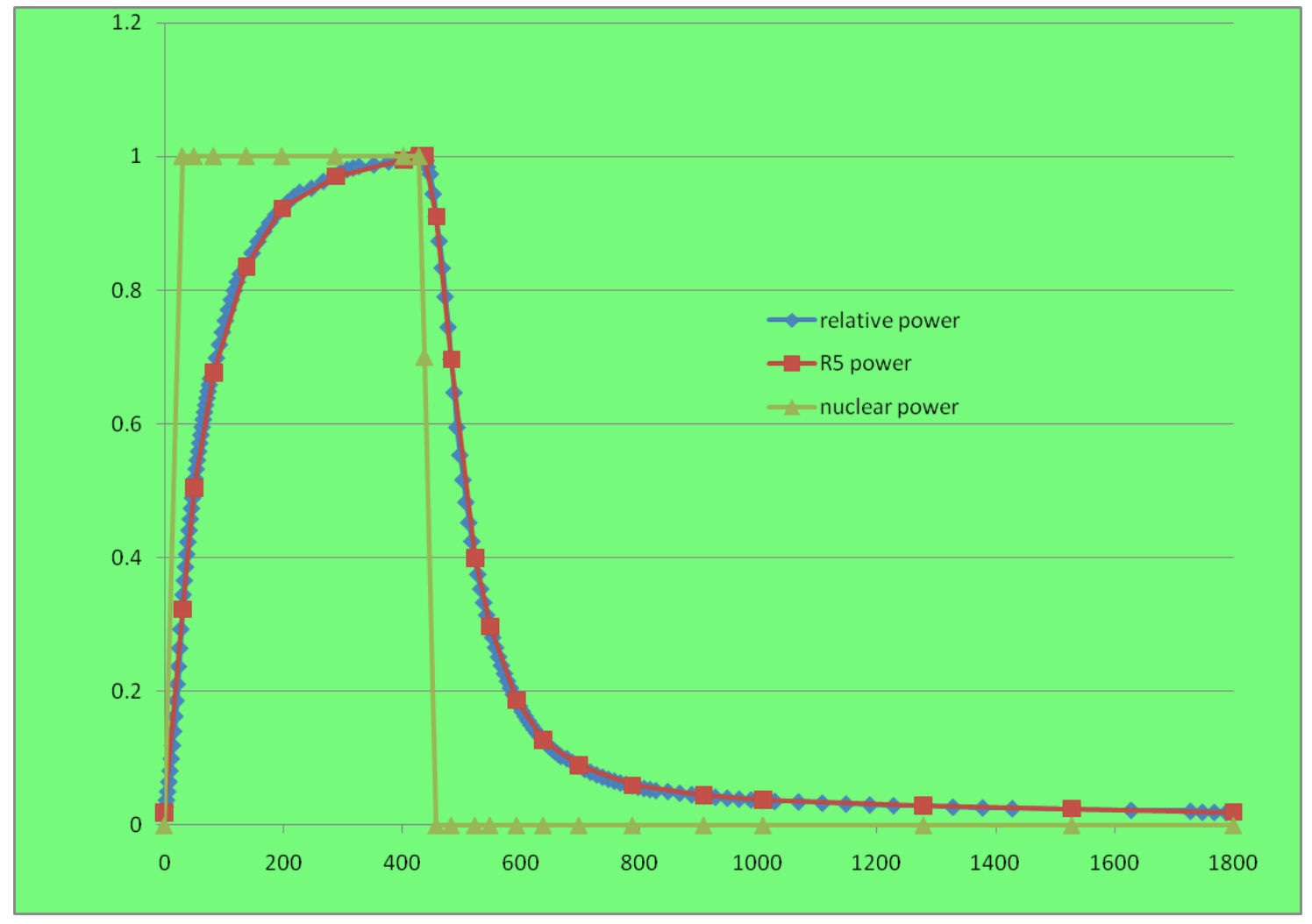

Fig. 12. Normalized power profile.

\section{SIMULATION OF POS}

The model developed is used to simulate the FW/BLK PHTS operation during the basic power mode-POS. The RELAP5-3D computer code is used and installed on a Windows PC.

The modeled state is characterized by a repetitive pulsing power with time intervals of $30 \mathrm{~min}$ (1800 seconds). The process is transient but with steady cycles of the system parameters. To reach those steady cycles, several pulses are simulated.

This simulation shows the general behavior of the time dependent PHTS thermal parameters during POS. Maintaining the coolant temperature and flow delivered to the blankets depends on the control logic used. Constant blanket inlet temperature and constant flow are specified by the blanket designers at this stage of the PHTS design.

The results presented here should be considered preliminary, approximate, and indefinite. They reflect a design stage with many unknowns, such as equipment operating characteristics, operation logic, etc. The model developed provides a framework to build on upon. As soon as information becomes available regarding the characteristics of specific equipment selected by the Architect Engineer, the model can be updated.

\subsection{PULSED POWER MODE}

The pulsing power during POS is taken from a detailed CFD thermal and flow calculation of the blankets. It is based on the thermal performance of a representative single blanket module (module 4 in this case). Four power pulses are simulated and are shown in Fig. 13. 


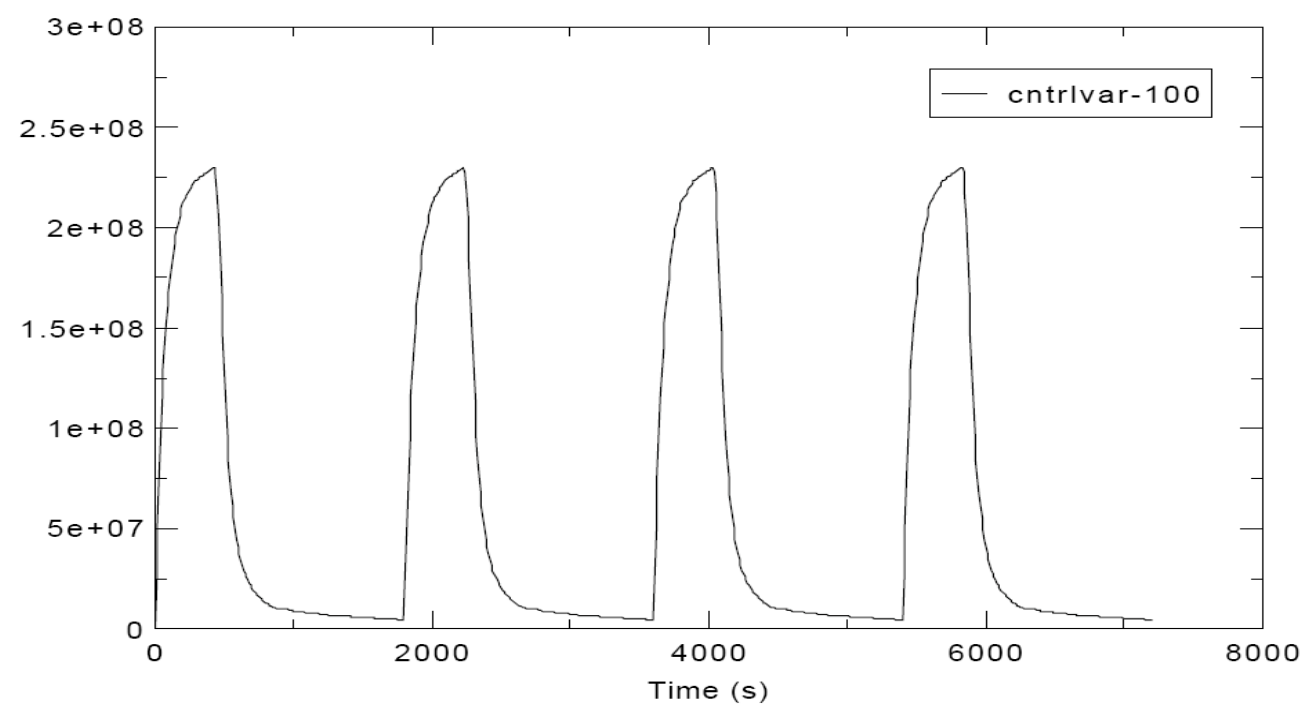

Fig. 13. Blanket power pulses.

The power is never zero because of the thermal inertia of the blanket metal structure even though the plasma is not burning. The degree of this residual heat is determined by the blanket module type.

Some blankets will have larger or smaller thermal inertia. As the blanket design advances, an appropriate (representative) blanket module needs to be selected to model the power to the PHTS.

\subsection{PRIMARY COOLANT TEMPERATURES}

The PHTS target control parameter is the cold-leg temperature, or the coolant temperature supplied to the blankets. The current requirement is that temperature is to be maintained at $100^{\circ} \mathrm{C}$ with 2 degrees of tolerance (margin). ${ }^{4}$ Flow control is used to achieve that temperature by controlling the amount of coolant running through the heat exchanger. In Section 1, the control logic for operating the valve regulating the flow through the heat exchanger is described.

The hot-leg temperature is the temperature of coolant returning from the blankets. These two temperatures are plotted in Fig. 14. The hot-leg temperature follows the power change, while the cold-leg temperature fluctuates based on the efficiency of the controlling mechanism, including both the control valve operation and the control logic. The deviation is $+3 /-2$ degrees, which does not comply with the requirement of 2 degrees in the positive direction. Since the purpose of this calculation is to show qualitatively the temperature evolution during a power pulse, no further changes to the control logic were made to improve the control of the cold-leg temperature.

An alternative option for temperature control would be to maintain a constant average temperature of the PHTS. This logic will minimize the expansion of the coolant during the pulse and thus will pose less load on the PRZ to accommodate the excess volume.

\subsection{MAIN AND BYPASS FLOWS}

The design requirement is to maintain a constant flow though the blankets. As previously discussed, to control the temperature, part of the flow is redirected through a heat exchanger. To keep the overall flow constant, a heat exchanger bypass line is used. Two valves control the flow by mirroring (when one opens, the other closes) each other during operation. The flow rates through these two valves are shown in Fig. 15. 


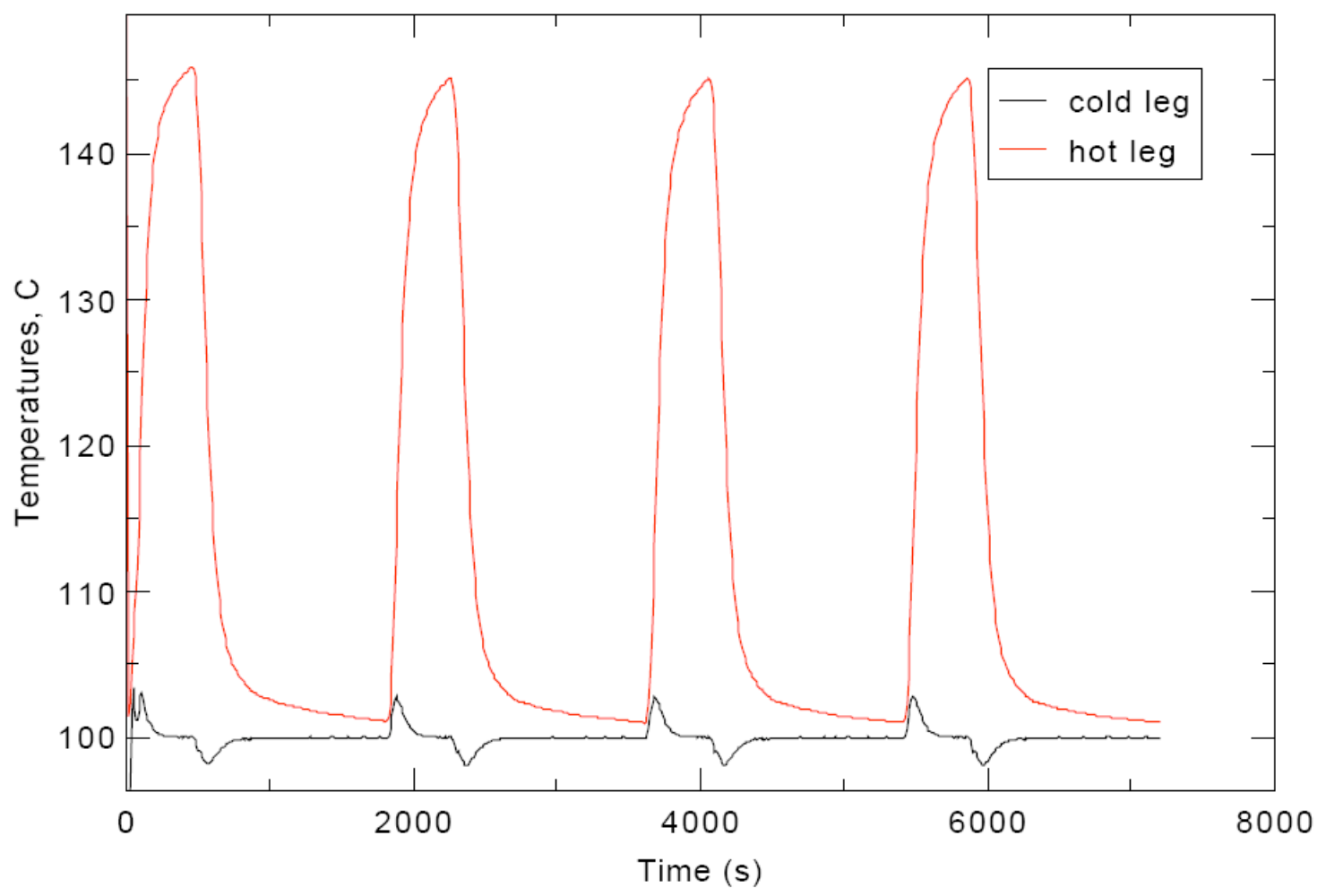

Fig. 14. Primary coolant temperatures.



Fig. 15. Mass flow rates. 
The total flow rate is about $1190 \mathrm{~kg} / \mathrm{s}$ and is kept essentially steady throughout the pulse. Small fluctuations are seen, caused by the change of the flow resistance when the valves operate. The heat exchanger line shows the flow passing through the heat exchanger. It is the flow required to remove the heat generated in the blanket. The magnitude of that flow is a measure for the heat exchanger thermal capacity, and it is seen that in this case the heat exchanger is very efficient and needs about $50 \%$ of the total flow to remove the heat. Therefore, it might be reasonable to consider a possible redesign of the heat exchanger. Another cause of this high efficiency can be the fouling of the heatexchanger tubes which is not taken into account in the present model. All of this is subject to further analysis and eventual model improvement.

The bypass valve, in the heat exchanger bypass line, operates opposite to the valve controlling the flow through the heat exchanger. This mode would be appropriate if the heat exchanger train and the bypass line would have the same flow resistance. In the current hydraulic design, this is not the case. An alternative to this mode would be a mode in which the heat exchanger valve controls the temperature of coolant going to the blanket, and the bypass valve controls the flow delivered.

\subsection{PRESSURE AND PRESSURE DISTRIBUTION}

The calculated pressure at different locations during the pulses is shown in Fig. 16. The plot also gives a picture of the major pressure distribution in the system.

One specific characteristic of the PHTS is the large pressure drop across the blankets which is about $1 \mathrm{MPa}$. This feature makes the hot part of the system run at much lower pressure than the cold part. This difference raises questions regarding the appropriate location of the PRZ (hot or cold side), which is discussed in Section 8.

The pressure difference between the blanket exit and the pump intake includes the losses in the heat exchanger. With all losses and elevation changes added, the lowest pressure in the system (pump intake) is almost equal to one-half of the highest pressure. Such a large pressure drop will require high pumping power, which may result in a custom pump design.

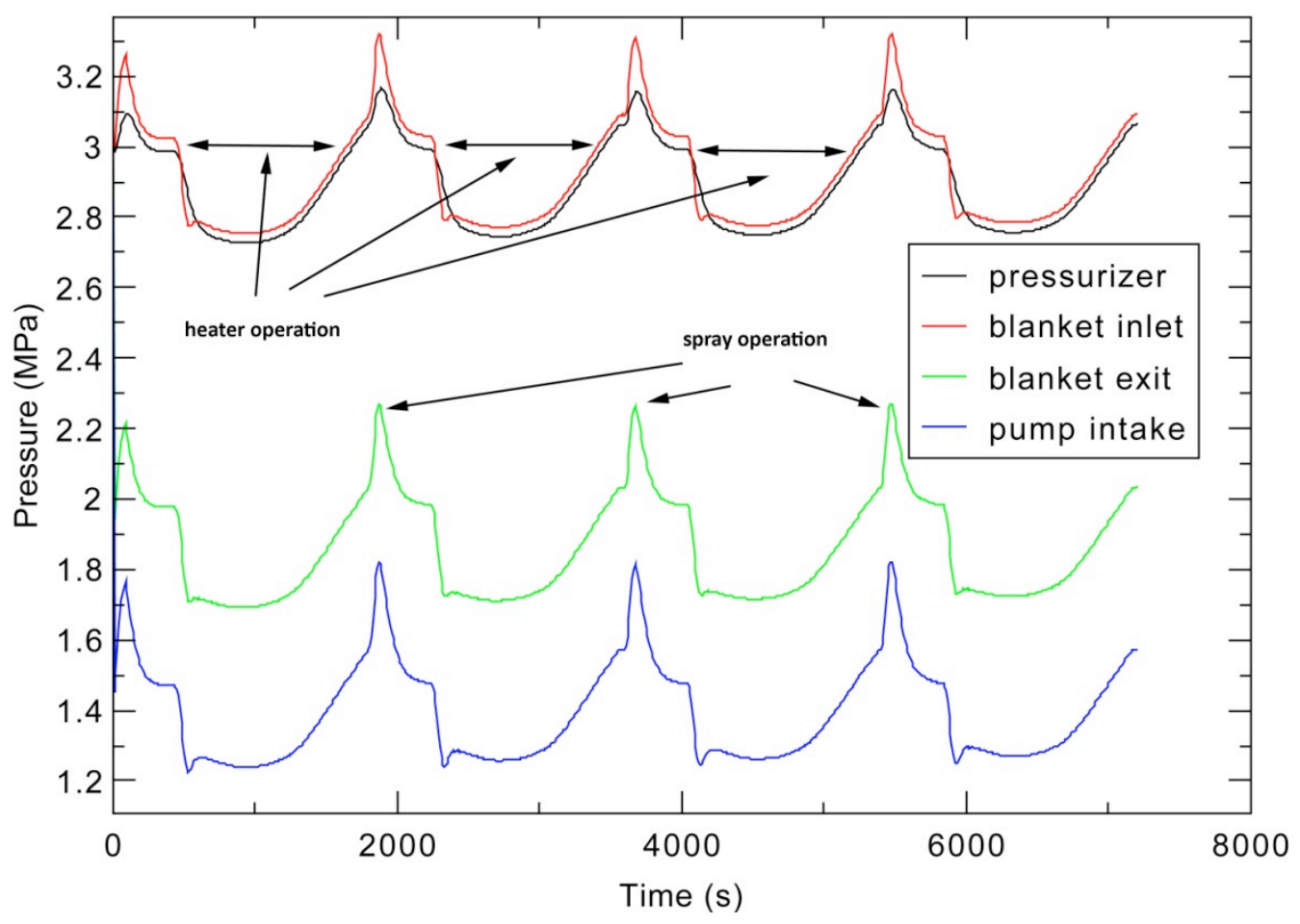

Fig. 16. Pressure at different locations. 
The pulsed power causes the temperature to change and the coolant to expand and contract. The amount of primary coolant volume resulting from that change needs to be accommodated by the PRZ while maintaining pressure within the acceptable tolerance band, which is $\pm 0.2 \mathrm{MPa}$ (Ref. 4).

The plot clearly shows the pressure fluctuation exceeds the required margin even though an active pressure control is applied. When the pressure starts to rise during the plasma power ramp, cold coolant with a maximum flow rate of $1 \mathrm{~kg} / \mathrm{s}$ is sprayed in the PRZ dome to reduce the pressure. Some sensitivity runs were made to assess the effect of the spray actuation set points as well as the spray flow rate. It was found that the rising pressure trend is quite high and that increasing the spray capacity most likely will not help. There are two negative consequences of spraying in the PRZ at every pulse: the primary inventory is unbalanced, and the coolant in the PRZ is cooled down.

Two questions arise from this finding: should an active pressure suppression control be used at all, or should the PRZ size be increased in order to maintain the pressure within the required limits? Another approach might be to increase the allowed pressure tolerance.

Similarly, the negative pressure spike is also not accommodated without an active control. The heaters operate to compensate for the effect of volume shrinkage. Their time response is slow because of the thermal inertia of the system. Heaters are located in the bottom of the PRZ where the cold coolant ingress from the loop decreases the local temperature, which is at saturation. This process postpones the time of vapor generation inception after the heater is turned on, further delaying the impact of heater operation on the primary pressure.

The large difference in the pressure spike at the blanket inlet and in the PRZ (Fig. 16) was found to be caused by the hydraulic resistance of the surge line. The current surge line diameter is $59 \mathrm{~mm}$, much smaller than the main coolant pipe $(482 \mathrm{~mm})$. Unless limited by other restrictions (space, thermal stress, etc.), it might be appropriate to increase the size of the surge line in order to minimize the pressure drop during in-surge events. If that is not possible, then the pressure used to control the spray and the safety valves has to be taken at the high-pressure side of the blanket (Section 9).

\subsection{PRIMARY COOLANT INVENTORY}

The primary coolant inventory is maintained by the CVCS. The measure of primary inventory is the level in the PRZ. A permanent spray in the PRZ of $0.4 \mathrm{~kg} / \mathrm{s}$ is established to keep the PRZ spray nozzles cooled. The number is a legacy number from the Belgatom model and should be adjusted if necessary. This spray flow rate is matched by the same letdown flow rate of the CVCS.

The PRZ level as a percentage of the total PRZ height is plotted in Fig. 17. The span of the level during the power pulse is less than $20 \%$, which is quite acceptable. The level shown in Fig. 17 is rising because of the spray operation used to mitigate the pressure spike. The model does not adjust the CVCS flow to accommodate the extra liquid injected by the spray.

No clear information exits on what PRZ level should be maintained by the CVCS during POS. Some sources suggest the level should be a function of the primary average temperature. This approach does not seem appropriate because both the level and the average temperature change during a power pulse and therefore most likely cannot be followed by the CVCS system. Some alternative approach is necessary. 


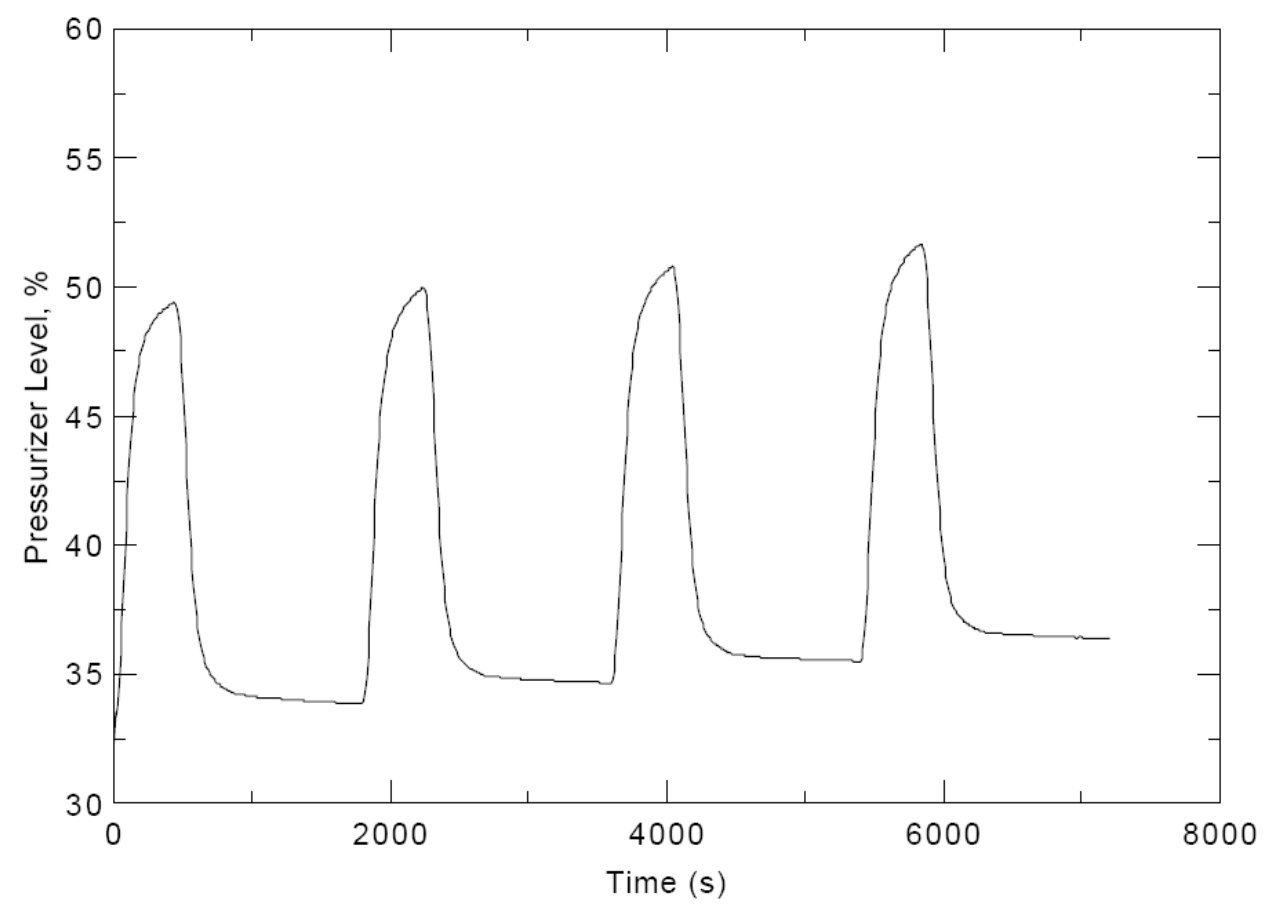

Fig. 17. Level in the pressurizer.

\section{SELECTION OF PRZ LOCATION (FW/BLK AND DIVERTOR/LIMITER PHTS)}

This section considers an existing analysis for selecting a location for the PRZ. ${ }^{8}$ The approach is based purely on safety concerns, although it confirms the conclusion made in the cited study.

The only possible physical location of the PRZ is in the vault 11-L4 (Ref. 3) where the main components of the PHTS are located. Within that vault, the PRZ can be in one of three places (Fig. 18):

1. On the cold side at the pump discharge - position 1, currently as shown in the figure

2. On the hot side before the heat exchanger-position 2

3. On the cold side upstream the pump (at pump suction)—position 3

The PRZ should not be placed in the variable flow part of the circuit, such as on the bypass line or between the heat exchanger and the control valve where it can remain partially or fully isolated from the remainder of the circuit during control valve operation.

\subsection{TYPE OF PRESSURIZER}

This analysis is done for a steam PRZ. An alternative to the steam PRZ could be a gas PRZ.

The steam PRZ has an increased inherent capability to compensate for pressure fluctuations by evaporating/condensing the steam naturally. It also allows the pressure to be reduced/increased by condensing the steam via spraying of cold water or boiling off some of the liquid by heating with a heater. An equivalent "gas PRZ" would have more rigid behavior (large resultant pressure variation). 




Fig. 18. Possible PRZ locations.

In order to keep the system fluid subcooled, the temperature in the PRZ has to be higher than the fluid temperature in the loop. This necessity creates thermal stresses in the PRZ connecting line (surge line).

Another feature of the steam PRZ is that the insurge flow (incoming water to the PRZ when pressure in the system increases) causes the water temperature in the PRZ to decrease. Because the insurge is always colder, the heater is required to operate to compensate for the thermal loss. It would therefore be desirable to have the insurge water temperature as high as possible to minimize the amount of power added by the heater necessary to keep the PRZ water at saturation. Additionally, the changing temperature in the surge line causes thermal fatigue which could be minimized if the temperature difference is smaller.

\subsection{OVER-PRESSURIZATION PROTECTION}

One of the PRZ safety functions is to provide over-pressurization protection of the circuit.

The analysis below presumes that the PRZ is equipped with passive safety valves performing controlled vapor discharge into a tank. A passive safety valve is a valve with settings that cannot be changed during operation. The valve opening set point is established to prevent the maximum pressure in the loop from exceeding the design pressure including margin.

A safety valve can be placed in locations other than on the PRZ, but then the discharge would be liquid. The vapor discharge is preferable over a liquid discharge when the system has a steam PRZ because the amount of discharged mass is minimal. 
It is possible to install active relief/safety valves. They allow for controlled steam release from the PRZ and allow resetting the safety set points when changing modes of operation. These devices are more expensive but are equally reliable.

\subsection{TOKAMAK SPECIFICS AFFECTING THE PRZ OPERATION}

The cooling loop is characterized by the following features that have an impact on the PRZ in performing its functions.

\subsubsection{Modes of Operation: POS and Baking}

The PHTS has different operating modes including: POS (plasma operation, pulsed power) and baking. The corresponding maximum system pressures are:

1. maximum pressure of $3.0 \mathrm{MPa}$ in POS mode

2. maximum pressure of $4.4 \mathrm{MPa}$ in the baking mode $^{3}$

The design pressure of the system is 5.0 MPa (Ref. 9). The margin between the design pressure and the baking pressure is small. To provide protection, the PRZ safety valve must be set up at some intermediate value, if a passive approach is taken.

As an alternative (active approach), the set points of the safety valves must be changed when the mode of operation changes (e.g., being different for the POS and baking modes).

\subsubsection{Large Pressure Losses on the FW/BLK Modules}

In POS mode: The FW/BLK represents a major flow resistance component with a pressure drop of around $1 \mathrm{MPa}$, when the system is in POS mode. Such a pressure loss is significant compared to the maximum pressure $(\sim 30 \%)$ and is compensated by the main pump. The heat exchanger is the second largest contributor to the circuit pressure losses with $0.2-0.3 \mathrm{MPa}$ pressure drop. The overall losses in the loop are about 1.3-1.5 MPa.

The above pressure drop characteristic divides the circuit into low $(\sim 1.5 \mathrm{MPa})$ and high $(\sim 3.0 \mathrm{MPa})$ pressure sides when the pump is working, with a difference between the two that is about half of the system pressure. The high-pressure side is from the pump to the blankets (cold side), and the low side is from the blankets to the pump (hot side).

If the pump is tripped and no active pressure control is performed, the pressure equalizes at some intermediate value (no flow pressure). The PRZ might be designed to have or not to have active pressure control after a pump trip, regardless of its location.

In baking mode: The pressure is set to $4.4 \mathrm{MPa}$, and because the flow rate is small, no large pressure losses occur around the loop. The hot and cold sides have similar pressures.

\subsubsection{Pulsed Mode of POS Operation}

The thermal power to be removed by the PHTS is not constant but is pulsed. The current POS mode (power mode) has a period of $1800 \mathrm{~s}$, where the full power period is $400 \mathrm{~s}$. There are ramp-up and shutdown periods ( 30 and $60 \mathrm{~s}$, respectively), which makes the total time that power is applied less than $500 \mathrm{~s}$. There is no generated (fusion) power in the remaining period of time. Because of the decay heat and the large FW/BLK metal structures, the thermal power to the PHTS is never zero even when there is no fusion power. This feature allows the temperature of the coolant to be controlled during the dwell periods (zero power).

The PHTS is designed to maintain a constant temperature of $100^{\circ} \mathrm{C}$ at the blanket inlet side (cold side). This is achieved by actively controlling the primary coolant flow through the heat exchanger. 
During the dwell period, the heat up in the blankets is small and the hot side temperature is close to $100^{\circ} \mathrm{C}$. The whole cooling loop is at low temperature. This design feature leads to thermal cycling of the hot part of the loop during each pulse.

\subsubsection{Long Delivery/Return PHTS Pipelines}

The main PHTS equipment (heat exchanger, pumps, PRZ, valves) is located about $130 \mathrm{~m}$ from the blankets. Coolant flow velocity is in the range of $4 \mathrm{~m} / \mathrm{s}$, which gives a travel time of more than 30 seconds from the blankets to the heat exchanger where the coolant heat is deposited.

When the coolant starts to heat up in the blankets, it expands and thus creates an insurge of water in the PRZ. The insurge temperature affects the PRZs ability to maintain pressure since an insurge cools the pressurizer fluid, as described previously.

If the PRZ were connected to the cold side of the loop, the insurge temperature would of course be cold. When the PRZ is connected to the hot side, the insurge temperature is not equal to the hotside temperature during the whole power pulse, because the PRZ location is a distance from the blanket. To evaluate the effect of the long return lines, a simulation was done with the PHTS model developed for the RELAP5 code and the results are shown in Fig. 19.

All parameters shown in Fig. 19 are normalized for comparison. Important in this case is the timing of the events. It is seen that about $25 \%$ of the insurge occurs at the cold temperature and about $75 \%$ at an intermediate temperature between the hot and cold sides. A very small part of the insurge occurs at the hot side temperature.

The result demonstrates that placing the PRZ on the hot side will have only a partial effect in terms of injecting hot fluid in the PRZ during the pressure rise period.

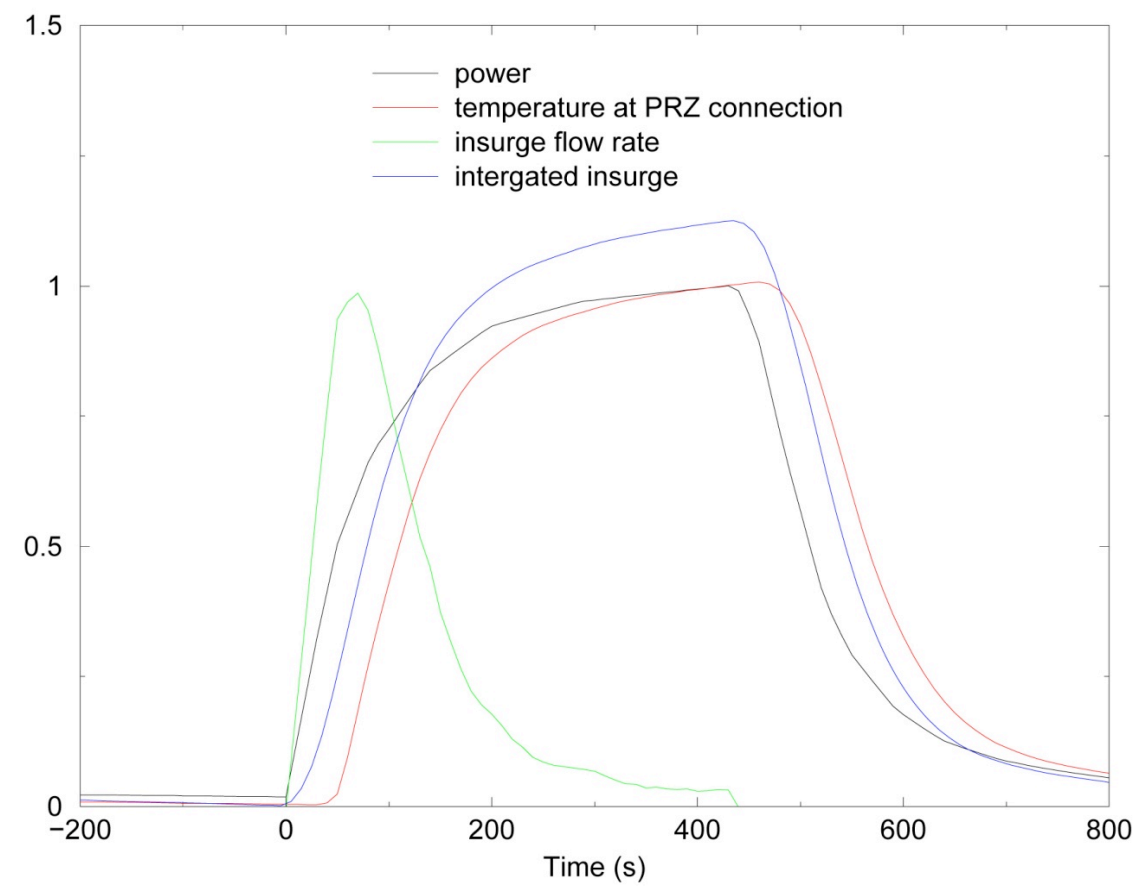

Fig. 19. Normalized insurge flow and temperature at the PRZ connection. 


\subsection{SELECTION OF PRZ LOCATION}

Providing over-pressurization protection is the criterion for the selection of the PRZ location.

From this perspective, the optimum location for the PRZ would be at the point where the pressure and temperature in the PHTS loop are the highest. The maximum pressure is needed to provide passive over-pressure protection, and the maximum temperature is needed to minimize the thermal stress and PRZ cooldown during an insurge.

With that said, position 3 in Fig. 18 can be discarded since it combines the lowest temperature with the lowest pressure point in the circuit.

The factors taken into account for the PRZ location selection are summarized below.

\subsubsection{Pump Trip Effect and Baking Mode Pressure}

The highest operating PHTS pressure is in baking mode (4.4 MPa). In POS mode (pressure of 1.5 to $3.0 \mathrm{MPa}$ ) when the pump runs, it builds up about half of the maximum pressure. Before starting the pump, or after tripping it, the system pressure will be at an intermediate value (e.g., between 1.5 and $3.0 \mathrm{MPa}$ ).

If the PRZ safety valve is of the passive type, it must be set at a value between the baking pressure (4.4 MPa) and the design pressure (5.0 MPa).

In the case where the PRZ is connected to the hot (low-pressure) side, and with the pump running, the pressure in the PRZ will be around 1.5 MPa. If the system pressure should start rising for some reason, the safety valve cannot provide protection because its setting, plus the pump head, will exceed the design pressure in the cold leg. The pump must be tripped to prevent over-pressurization of the cold leg. Such an active action may jeopardize the integrity of the system.

In the case where the PRZ is connected to the cold (high-pressure) side, there is no risk for the system to be over-pressurized because the PRZ is always connected to the highest pressure point.

\subsubsection{Cold versus Hot Insurge Flow}

As previously mentioned, the improved response to insurge and outsurge transients expected by placing the PRZ on the hot side is only partial because of two factors: the hot side is filled with cold coolant during the zero power period, and the pipes are long enough so the resultant insurge of coolant into the PRZ is only partially from hot fluid.

\subsubsection{Passive and Active PRZ Safety Valves}

The analysis is done presuming passive safety valves. If active valves are installed, then their setting could be easily changed depending on the mode of operation: baking or plasma (POS) and the PRZ could be placed on any side of the coolant loop.

\subsubsection{Position of PRZ}

Based on these factors, it is more appropriate to place the PRZ in position 1 (the pump outlet) which will provide better over-pressurization protection but at the same time will cause a deterioration in the PRZ thermal conditions caused by cold fluid injection during periods where the pressure increases. This will result in the need for increased PRZ heater power.

If an active PRZ safety/relief valve is installed with a variable setting, then it is better to place the PRZ on the hot side before the heat exchanger (position 2).

The analysis is done for specific design and operating pressures (POS and baking). If those change, it needs to be reevaluated. 


\section{CONCLUSIONS AND RECOMMENDATIONS}

The RELAP5 model of the FW/BLK PHTS was run to simulate several consecutive power pulses of POS mode of ITER operation. The model reflects the current design state, which is not final. To that extent, the conclusions here are not definite and require revision after changes in the equipment characteristics or functions are made.

- One of three FW/BLK PHTS loops is simulated that is designated to remove one-third of the total plasma power.

- The system is modeled up to the blanket manifolds; the FW/BLK are not modeled but are represented as a lumped component.

- The power of the blanket component has been calculated in detail ${ }^{7}$ and is used as an input condition here. A representative blanket module is used in the detailed CFD calculations.

- POS mode is simulated, and four consecutive power pulses are computed. A power control component is developed in the RELAP5 code to periodically repeat the power pulses.

- The system target parameter is the coolant temperature supplied to the blanket. Some control instrumentation and control logic is applied to maintain that temperature, which was taken from the input data developed by Belgatom. ${ }^{1}$

- The pulsed power causes the system parameters to fluctuate. Both the temperature and, in particular, the pressure fluctuations are larger than the limits established by the design. ${ }^{9}$

- The large pressure drop on the blanket is a specific feature of the system that requires special attention. The maximum (design) pressure is almost two times higher than the minimum pressure in the system. Because this pressure drop is compensated by the pump operation, turning the pump off will significantly redistribute the pressure in the system.

- The heat exchanger design in this model has the primary coolant flowing on the tube side.

Based on these preliminary analyses, the following systems and components need to be revised as the design progresses:

- The blanket power module is presently represented as a lumped blanket component. The representative blanket module thermal data need to be updated periodically as the blanket design progresses.

- Control and bypass valve characteristics and control logic.

- Main pump data - the built-in RELAP5 pump data that have been used here need to be replaced by real pump data.

- Branch pipes, the current design of which will most likely change. The lower section of the branch piping has some uncertainty in the layout that needs to be clarified.

- Final heat exchanger design is still not available. Once completed, the design will have to be implemented in the model. 


\section{REFERENCES}

1. BELGATOM. (2003). First Wall/Blanket Cooling System Simulation and Safety Analyses (Athena). TIERSDI4NT4659.

2. APT. (2007). Symbolic Nuclear Analysis Package (SNAP).

3. U.S. ITER. (2009). Conceptual Design Report. US ITER 12100-TD0005-R00.

4. Nishikawa, A. (2000). Design Basis on Primary First Wall and Blanket PHTS for ITERFEAT. N 26 MD 30 99-11-17 W 0.3.

5. Yoder, G. (2009). Shell and Tube Heat Exchanger Design.

6. Kim, S. (2009). ATF Fathom Model.

7. Ying, A. (2009). Personal communication with Alice Ying CFD Analysis for BM04 Model.

8. App2, D.-2. (1997). Consideration for Pressurizer Type and Location.

9. DDD-26. (2004). Design Description Document, Cooling Water System. 


\section{INTERNAL DISTRIBUTION}

1. J. B. Berry

2. J. J. Carbajo

3. J. J. Ferrada

4. S. H. Kim
6. K. L. Wilcher

7. G. L. Yoder, Jr.

8. File-USIPO DCC-RC

\section{EXTERNAL DISTRIBUTION}

9. W. Curd, ITER International Organization, St. Paul Lez Durance Cedex, France 13607

10. G. Dell'Orco, ITER International Organization, St. Paul Lez Durance Cedex, France 13607 